\title{
Competitive Strategy of Firms' Participation in the Global Value Chains and Labor Income Share
}

\author{
Zhaoji Sun (iD, ${ }^{1,2}$ Danling Tang, ${ }^{2}$ and Qing $\mathrm{Li}^{1}$ \\ ${ }^{1}$ Guangdong Institute for International Strategies, Guangdong University of Foreign Studies, Guangzhou 510420, China \\ ${ }^{2}$ Southern Marine Science and Engineering Guangdong Laboratory (Guangzhou), \\ Guangdong Key Laboratory of Ocean Remote Sensing, State Key Laboratory of Tropical Oceanography, \\ South China Sea Institute of Oceanology, Chinese Academy of Sciences, Guangzhou 511458, China \\ Correspondence should be addressed to Zhaoji Sun; szjszl1988@163.com
}

Received 24 September 2021; Revised 14 November 2021; Accepted 19 November 2021; Published 7 December 2021

Academic Editor: Zhipeng Tang

Copyright (๑) 2021 Zhaoji Sun et al. This is an open access article distributed under the Creative Commons Attribution License, which permits unrestricted use, distribution, and reproduction in any medium, provided the original work is properly cited.

\begin{abstract}
The division of labor in the global value chain (GVC) has reshaped the competitive advantage of enterprises participating in the international market and has a significant influence on the distribution of their factor income. Based on the perspective of market choice, this paper uses China's industrial enterprises' data, Customs Statistical Data on Import and Export, Word Input and Output Database (WIOD), and BACI database from 2000 to 2007 to analyze the effect of competitive strategy of a firm's GVC participation on its labor income share. Herein, the competition strategy is depicted by the quality and price of export goods. The empirical results show the following. (1) Quality competition has a larger effect on labor income share than price competition. High-quality and high-price or high-quality and low-price strategies tend to have a significant negative effect on labor income share, while low-quality and low-price and low-quality and high-price strategies have a positive effect. (2) The higher the target market GVC status, the lower the labor income share of exporting firms, and the target market GVC status amplifies that the highquality and high-price strategies on firms' labor income share the negative effect of high-quality and low-price strategies on exporters' labor income share. (3) High-quality and low-price strategies have a significant negative effect on exporters' labor income share when competing with developing countries in developed country markets or with developed countries in developing country markets. However, the positive effect of low-quality and low-price strategies and low-quality and high-price strategies kept unchanged. The findings remain robust after controlling for endogeneity and accounting for the effects of firm heterogeneity, indicator measurement, and sample variation.
\end{abstract}

\section{Introduction}

Letting some people get rich first and eventually achieving common prosperity is an important path for China to improve people's living standards through reform and opening up. Achieving common prosperity includes two dimensions: the increase of overall prosperity and the sharing of development achievements. The continuous rapid growth of economic output over the past 40 years has significantly increased China's overall prosperity, while the sharing of development achievements needs further improvement. The report of the 19th National Congress of the Communist Party of China proposed that "socialism with Chinese characteristics has entered a new era, and the main contradiction in our society has been transformed into the contradiction between people's growing need for a better life and unbalanced and insufficient development." The unbalanced development is mainly reflected in the differences among people, regions, and urban and rural areas, and the differences among people have become an important aspect that hinders the sharing of development achievements. Since the mid-1990s, the share of labor income in China has been declining [1], and the continuous decline in the share of labor income is an important reason affecting the distribution of residents' income which has attracted widespread concern from all sectors of society. In response, the report of the 18th National Congress points out that "the share of labor compensation in the initial distribution should be 
increased, and the mechanism of initial distribution should be improved so that factors are distributed according to their contribution."

In an open economy, according to the StolperSamuelson theorem (SS Theorem), the share of labor income in China should increase with the expansion of international trade, but the opposite is true. The period of declining labor income share is the period when China actively participates in the global value chain (GVC) competition, which provides a stimulus for the research in this paper. Based on this, this paper investigates how the competitive strategies adopted by firms when facing different competitors in different markets affect the labor income share of firms? How does this impact relate to the GVC status of the target market? The research in this paper contributes to improving the initial factor income distribution to achieve common prosperity in an open economy and also provides empirical evidence from Chinese manufacturing industries to study the impact of competitive strategies on factor income distribution.

\section{Literature Review}

The decline in many countries' labor income share since the 1980s has driven scholars to rethink the changes in it. They have explained the variation from domestic perspectives of industrial structural transformation, policy and system reform, biased technical progress, and labor markets. Empirical research by $\mathrm{Lu}$ and Tian found that industrial concentration has a significant negative effect on the share of industrial labor income, and the main reason for the simultaneous decline in the labor income share of various industries is the division of enterprise scale within the industry [2]. The "VAT reform" has increased the labor income share of China's service industry export enterprises [3]; the minimum wage regulation has allowed enterprises to change the allocation of factors and reduce the labor income share of China's industrial enterprises [4]. The shareholding reform has significantly reduced the labor income share of listed companies in China, with a significant negative effect especially on state-owned labor-intensive enterprises [5]. The capital-labor elasticity of substitution in China is significantly greater than 1 , and the decline in the relative price of labor leads to a decrease in labor income share [6].

Under open economy conditions, international trade affected labor income shares through the following channels such as endowment differences [7], labor-management bargaining power, and technological progress bias [8, 9]. According to neoclassical trade theory, developed countries have larger advantages in capital endowment than labor compared with developing countries. International trade has lowered the labor income share in developed countries, while it has raised that of developing countries. In fact, the decline in labor income share is a global phenomenon [10]. Decreuse and Maarek used the trade dataset for 8 OECD countries over the period 1970-2005 to conduct analysis and found that other countries' trade intensity with China explained between $30 \%$ and $60 \%$ of their labor share decline [11]. Elsby et al. also found that it was the extensive imports of Chinese products that drove the US labor share decline [12]. International trade has lowered the bargaining strength of the above countries' laborers and led to the decline in their labor share. Labor bargaining power is significantly positively correlated with its income share [13]. The stability of trade policy has a positive effect on labor bargaining power, so more stable trade policies can help increase the labor income shares [14].

From the existing studies, the relationship between exports and labor income share in China has not been consistently concluded. Applying the income distribution theory of the Post-Keynesian conflicting claims model, Tang used the provincial panel data over the period of 1995-2007 to conclude that exports have significantly improved China's labor share [15]. Using China's industrial enterprises' data from 1998 to 2007, Zhou et al. found a similar relationship for enterprises [16]. Using Chinese industrial enterprise data from 2004 to 2009, Wu and Shao find that export trade increases the labor income share of manufacturing firms, especially more significantly for labor-intensive SMEs. [17]. However, the empirical analysis from Zhang et al. has shown exports squeezing the increase of China's manufacturing enterprises' labor share [18]. Zhang et al. constructed an equation that described the decision of factor income distribution and used the cross-country data from 1980 to 2007 to conduct analysis [19]. Their conclusions showed that international trade led to a bias toward technical progress and thus lowered the labor income share. Findings from Xiao and Zhou showed that it was mainly due to the transformation of exports trade mode that China's labor income share has seen a trend of rise first and then fall during the period of 1993 and 2007 [20]. Peng and Zhang constructed the international division of labor income model under different trade types and found that Chinese processing trade and general trade income both showed a trend of first rising and then falling [21].

Besides exports, some scholars tried to explain the relationship between international trade and labor income share from the perspective of trade liberalization. Trade liberalization affected China's labor share via factor price and technical progress [22]. However, there have been great disparities in empirical conclusions. Böckerman and Maliranta conducted research based on microenterprises, and they held that the negative effect of trade liberalization on industry labor share emerges through existing plants, i.e., those with low productivity [23]. Trade liberalization has a positive effect on labor share within Chinese enterprises and intermediates trade liberalization lowered labor income share in Chinese enterprises $[24,25]$. However, the relationship between trade liberalization and labor income share in India, which is also a developing country, is uncertain and is related to the size of the firm and whether it is labor-intensive [26]. With technical progress and a decrease in circulation costs, exports categories have shifted from final consumer goods to intermediate inputs. International specialization has transformed from intraproduct and horizontal interindustries specialization to that among factors and within value chains. The global value chain is formed therein. Multinational companies in developed 
countries have reconstructed their value chains based on their core competencies, and local Chinese enterprises mostly participate in global value chains by means of OEM and OEM production [27]. In this way, Chinese enterprises have seen rapid development, but they have gained slimmer margins in the GVC specialization system [28]. Sui et al.'s research found that the degree of embeddedness and upstream degree of the global value chain significantly affects the share of corporate labor income $[29,30]$. The lower-end Embed method is reasonable in certain stages, while the high cost of labor factor cannot be ignored. The demographical dividend is disappearing, and other developing countries such as India and Vietnam are engaging in GVC competition. Under this condition, Chinese export enterprises need to seek changes in their competitive strategies in GVC participation [31].

Using Chinese customs statistics from 2000 to 2006, Li et al. find that Chinese exporters mainly adopt the "lowquality and low-price" competition strategy, especially private enterprises that newly enter the export market and enterprises in the eastern region are more inclined to compete at low prices [32]. Liu and Ding used the United Nations trade database and conducted a triple-dimension marginal decomposition and found that the driving forces of export increase have been shifted from quantitative types with low-quality and low-price to price driving forces with high-quality and high-price [33]. Based on analysis of BACI national data, Han and $\mathrm{Yu}$ held that since China joined WTO, it has seen a consistent decrease in the unit price of exports and improvement in exports quality. Enterprises tend to high-quality and low-price strategies [34]. However, compared with those of countries with high income, the quality of Chinese exports is still low, and export expansion is more reliable on price index decrease [35]. Fan and Guo inspected enterprises' pricing strategy using China's industrial enterprises' database and China customs database over the period 2000-2006. They found that when their export products are homogeneous, enterprises with high productivity have lower export prices, while the opposite is true under the heterogeneous framework [36]. An empirical study based on Greek export data found that reduced credit constraints are more likely to make companies choose highquality and high-price competitive strategies [37].

Exporters' choice of competitive strategy varies depending on the global value chain in which the export market is located and the competitors. Different markets have a different extent of sensitivity to price and quality. In detail, countries lying in the lower-end in GVC have a low requirement for quality. In such countries, enterprises resort to price competition by factor price advantages. However, enterprises exporting to those countries lying in the higherend in GVC tend to adopt a quality competition strategy [38]. Luo and Wei applied United Nations trade data over the period 2007-2012 and took the machinery and transportation equipment industry as an example to inspect the exporting price competition effect between China and medium- and high-income countries [39]. Findings showed that there exists a significant price competition relationship with different intensities in different markets. Exporting enterprises adjusted their competitive strategies facing different competitors. It is due to this that competition with high-wage countries led to improvement in Chinese enterprises' exporting goods [40]. However, competition within Chinese industries has driven enterprises into taking low-price strategies [41]. External shocks cause firms to produce heterogeneous responses of endogenous quality and pricing strategies [42]. Zhong and Yu studied the impact of external demand shocks and found that multiproduct enterprises that adopt quality competition strategies encounter external demand increases, the export price of core products will increase, while the reaction of multiproduct companies that adopt cost-competitive strategies is the opposite [43].

With the deepening specialization of global production, different countries have participated in the production processes, and intermediates have flowed across countries many times. Traditional trade statistics record trade flows on a gross basis, leading to a serious double-counting problem. The trade scale under the traditional trade statistic framework cannot truly reflect the benefit distribution, that is to say, what you see is no more than what you get [44]. Taking into account the difference in value-added capabilities between production processes, by constructing nonequidistant industry upstream indicators, it is found that the smiling curve is not universal, and FDI makes territorial export value added cannot truly reflect the factor income structure of foreign-funded enterprises $[45,46]$. So trade scale cannot reflect the accurate effect of international trade on labor income share, and we have analyzed the effect of enterprises' GVC participation strategies on their labor income share. The marginal contributions in this paper are mainly in the following three areas. Firstly, under the background of economic globalization, current works of literature have analyzed how international trade affected labor income share from perspectives of import and export behaviors and trade liberalization $[24,26]$. Among the rare researches into labor share based on GVC, existing papers mainly conducted macrolevel empirical analysis of GVC participation and GVC position [47, 48]. In this paper, we have made an analysis of the effect of exporting enterprises' competitive strategy choices in GVC on their labor income share from the view of market choice, hoping to provide us with a comprehensive understanding of how international trade affects labor income share.

Secondly, the existing literature tends to adopt the unit value method to measure product quality $[49,50]$. This system usually assumes that high price reflects high quality, while low price reflects low quality without disentangling quality from price $[32,33]$. The unit value method uses unit product price to directly reflect its quality and assumes that products' quality is totally reflected in their price, resulting in serious errors. Another method based on demand-side information to measure product quality has disentangled quality from products price and stated that on condition of price, imports with higher market shares are assigned higher quality. This method has considered consumers' preference for quality but has ignored the fact that enterprises themselves have a decisive role in the products' quality [51-53]. 
Base on this method, the latest method has utilized both demand-side and supply-side information to measure products' quality, which is more accurate $[54,55]$. Li and Jiang identified national competitive strategies using relative price and commodities' quality [56]. Based on the researches of Feenstra and Romalis, and Yu and Zhang, we have adopted demand-side and supply-side information to infer the exporting goods' relative quality from the macronational level and microenterprise level and to construct the enterprises' relative quality compared with the world's average level. In this way, we used China Customs statistic data and the BACI database to measure the relative price at the national and enterprise levels and to construct the enterprises' relative prices. Applying the method of Li and Jiang, we identified enterprises' exporting strategies using their relative quality and relative price. This competitive strategy responds to the firm's position in the world average quality and price levels, not just the firm's position among all firms in the country, and can reflect both firm and country characteristics.

Thirdly, current researches usually focus on the GVC position of domestic countries $[57,58]$, ignoring that of the aim markets. In this paper, we used the improved GVC position index to measure the GVC position of the enterprise's aim market, combining the GVC position with the competitive strategy. GVC position index constructed by Koopman et al. did not consider the returned domestic value added (RDV) and did not eliminate pure double-counting of foreign value-added in a country's exports (FDC), either. However, FDC can only indicate GVC participation and is not very helpful in explaining the location of GVCs $[59,60]$, so this article will improve on this basis.

\section{Competition Strategy and Measurement of Target Market's GVC Position}

\subsection{Identification of Competition Strategy}

3.1.1. Measurement of Enterprises' Export Product Quality. Drawing on the method of Yu and Zhang, the supply-demand information extrapolation method is used to measure the quality of enterprise export products [55]. Due to large amounts of import intermediate inputs used in the processing trade, the quality of exporting products cannot be measured accurately. What's more, enterprises undertaking processing trade can only choose limited competition strategies. To make it feasible, we only conduct analysis of general trade situations. Structural parameters including exporters' FOB unit price, enterprises' productivity, and input cost are constructed to measure the quality of the exporting products. Exporters' FOB unit price $u v_{i j g t}$ was calculated using China Customs statistical data over 2000-2007. $u v_{i j g t}$ denotes the FOB unit price of product $g$ produced by enterprise $i$ exporting to country $j$.

$$
u v_{i j g t}=\frac{\text { value }_{i j g t}}{\text { quantity }_{i j g t}} .
$$

In equation (1), we define value $_{i j g t}$ as the $\mathrm{FOB}$ value of enterprise $i$ 's product $g$ exporting to country $j$ in the year $t$. quantity $_{i j g t}$ represents the exporting amount. We aggregated from the 8-digit HS to the 6-digit HS and uniformed HS 1996 and HS 2007 into HS 2002.

Enterprise's productivity $\varphi_{i t}$ was measured using the OP method based on Industrial Enterprise's Database over 2000-2007. According to the method of Brandt et al. [24], we calculated deflators and made unification of industry code consistent with the year 2002. Total factor productivity was estimated based on 4-digit CIC (Chinese Industry Classification).

Inputs include labor, capital, and intermediates. Total input costs were based on these three factors' costs, and the average industrial input cost $w_{t}$ can be obtained by the following equation:

$$
\ln \left(w_{i t}\right)=\alpha^{\prime} \ln \left(w_{t}^{L}\right)+\beta^{\prime} \ln \left(w_{t}^{K}\right)+\gamma^{\prime} \ln \left(w_{t}^{M}\right) .
$$

In the above equation, $w_{t}^{L}, w_{t}^{K}, w_{t}^{M}$ and $\alpha^{\prime}, \beta^{\prime}, \gamma^{\prime}$ represent the unit input cost of labor, capital, and intermediate, and their respective share. Since intermediates used to produce general exporting goods are mainly from domestic countries, the unit input cost equals 1 at the equilibrium. And we obtain the actual average industrial input cost $w_{t}$ through equation

$$
\ln \left(w_{i t}\right)=\alpha^{\prime} \ln \left(w_{t}^{L}\right)+\beta^{\prime} \ln \left(w_{t}^{K}\right) .
$$

In this equation, $w_{t}^{L}=\left(\right.$ wage $_{t}+$ compensation $\left._{t}\right)$ /employee $_{t}$ and $w_{t}^{K}=$ depreciation $_{t}$ /capital $_{t}$. wage $_{t}$ and compensation $_{t}$ refer to the enterprise's total payable wages and total welfare funds, respectively. employee ${ }_{t}$ is the employment. Adding wages and welfare funds over 2-digit CIC and then deflating, we can get the labor cost. We denote depreciation $_{t}$ and capital $_{t}$ as enterprise's depreciating value of fixed capital and total fixed capital, respectively. In the C$\mathrm{D}$ production equation, $\alpha^{\prime}=\alpha /(\alpha+\beta+\gamma)$ and $\beta^{\prime}=\beta /(\alpha+\beta+\gamma)$. While estimating the total factor productivity, we can get the output elasticity $\alpha, \beta, \gamma$ at the 2 -digit CIC.

Adopting the structural parameters of 4-digit SITC Revision 2 of all countries in each year proposed by Feenstra and Romalis [54], we used the concordance file of SITC and 6 -digit HS to create the structural parameter $\theta_{g}$ and $\kappa_{j g t}$ of the 6-digit HS goods.

Matching all the above parameters, the quality $\ln \left(z_{i j g t}\right)$ of certain enterprise's products exporting to destinations in the year can be obtained by

$$
\ln \left(z_{i j g t}\right)=\theta_{g}\left[\ln \left(\kappa_{j g t}\right)+\ln \left(u v_{i j g t}\right)+\ln \left(\varphi_{i t}\right)-\ln \left(w_{t}\right)\right] .
$$

To avoid the influence of extreme values, the extreme values of $1 \%$ before and after are removed under HS6 codes. The obtained product quality $\ln \left(z_{i j g t}\right)$ can be compared within one good across the country and across time. In order to get the product quality at the enterprise level, the product quality is standardized as follows. 


$$
\text { qual }_{i j g t}=\ln \left(z_{i j g t}\right)-\ln \left(z_{10 \%-g}\right) .
$$

In equation (5), qual ${ }_{i j g t}$ is the normalized products quality index, and $\ln \left(z_{10 \%-g}\right)$ is the $10 \%$ quartile of the same 6 -digit HS category product's quality. Based on the data proposed by Feenstra and Romalis [54], we utilized both demand-side and supply-side information to obtain the quality of 4-digit SITC exporting goods and then got the relative quality $r q_{i j g t}$ of China's exporting enterprises based on the concordance file of SITC and 6-digit HS. Details are as follows:

$$
r q_{i j g t}=\text { qual }_{i j g t} *\left(\frac{\mathrm{cqual}_{j g t}}{\text { wqual }_{j g t}}\right),
$$

cqual $_{j g t} /$ wqual $_{j g t}$ is the ratio of the quality of product $g$ exporting to country $j$ from China in the year $t$ and the average quality of product $g$ exporting to country $j$ from all over the world. The relative quality of enterprise $i$ 's product $g$ exporting to country $j$ can be obtained by multiplying the relative product quality of enterprise $i$ compared to that of all domestic enterprises by that of China compared to the world. Adding by the exporting volume weight based on the relationship between exporting goods and exporting destinations, we can get the relative exporting quality of enterprise $i$ in the year $t$ and denoted as $\mathrm{rq}_{\mathrm{it}}$.

3.1.2. Measurement of Enterprise's Exporting Product Price. In light of the method from $\mathrm{Li}$ et al. and $\mathrm{Li}[32,40]$, we measured the enterprises' relative exporting price $r p_{i j g t}$ based on China Customs Statistic Database and BACI database. The specific calculation formula is as follows:

$$
r p_{i j g t}=\left(\frac{u v_{i j g t}}{u v_{j g t}}\right) *\left(\frac{c u v_{j g t}}{w u v_{j g t}}\right)
$$

where $u v_{i j g t} / u v_{j g t}$ is the ratio of FOB unit price of enterprise $i$ s product $g$ exporting to country $j$ in the year $t$ and that of all enterprises' product $g$ exporting to country $j$. We applied Customs Statistic Database over the period of 2000-2007 to calculate. We constructed $c u v_{j g t} / w u v_{j g t}$ which denotes the ratio of the unit price of product $g$ exporting to country $j$ from China in the year $t$ and that of product $g$ exporting to country $j$ from all over the world. BACI database of 2000-2007 is used to measure the ratio. By making unification of industry code into 2002 version of 6-digit HS, we can obtain the relative price of enterprise $i$ 's product $g$ exporting to country $j$ and that of all countries' product $g$ exporting to country $j$. (Prices in the BACI database were obtained by deducting trading costs such as transporting cost and insurance and unifying differences of all countries' product quantity based on United Nations trade data. Besides, due to the large share of transshipment trade of Hong Kong and Singapore, we dropped samples of Hong Kong and Singapore when measuring enterprises' relative exporting prices.) Adding by the exporting volume weight based on the relationship between exporting goods and exporting destinations, we can get the relative exporting price of enterprise $i$ in the year $t$ and denoted as $r p_{i t}$.
3.1.3. Exporting Competition Strategy. Using relative quality $r q_{i t}$ and relative price $r p_{i t}$, we applied the method of Li and Jiang to construct enterprises' competition strategies [56]. An enterprise can choose a low-price strategy or a high-price strategy. We define the low-price competition strategy as an enterprise choosing the price level lower than the average price of all enterprises; otherwise, it is the high-price competition strategy. Regarding quality, an enterprise can also choose a low-quality competition strategy or a highquality competition strategy. Similarly, a low-quality strategy comes when an enterprise's exporting quality is lower than the average level, otherwise forming the high-quality strategy. The competitive strategies of firms are defined as shown in Figure 1.

3.2. GVC Position of Target Markets. Koopman et al. have defined GVC position indexes [60]. Based on the decomposition framework proposed by Wang et al. [61], we have improved the reimport index to contain returned domestic value-added (RDV) part and dropped the pure double counting (FDC) of foreign value-added (FV). The modified index is stated as follows:

$$
\mathrm{GVC}_{-} \operatorname{Position}_{k}=\operatorname{Ln}\left(1+\frac{\mathrm{IV}_{i}+\mathrm{RDV}_{k}}{E_{k}}\right)-\operatorname{Ln}\left(1+\frac{\mathrm{FVA}_{k}}{E_{k}}\right) .
$$

In formula (8), IV represents the sum of domestic value added contained in the intermediates' export absorbed by direct importers and that contained in the intermediates produced by direct importers exporting to the third country and absorbed by the third one. FVA refers to the foreign value added contained in domestic exports and absorbed by other countries. $E$ is the total exports, with the subscript $k$ representing countries. The WIOD database is used to measure the GVC status of each country, and Figure 2 shows the GVC status of major countries and the comparison before and after modification.

From Figure 2, we can see that developed countries' GVC positions have been underestimated to a different extent, especially those of the United States and Germany. The decomposition results tell us that the sum of RDV and FDC accounts for $11.0 \%, 7.7 \%$, and $4.7 \%$ of reimports in exports in the United States, Germany, and China, respectively, due to which that the GVC positions of the United States and Germany have been underestimated. For the USA, its underestimation is mainly attributed to the large share of RDV contained in the reimports of exports, while for Germany, FDC accounts for more. Major resources exporters like Russia and Brazil have high GVC positions without much change after modifying the index. The GVC position of India and Germany has shown the most obvious declining trend during this period, especially that of India since 2003. Considering the large share of China's exports to developed countries, our modification of the index will lead to a more accurate measurement of target markets' GVC position. 


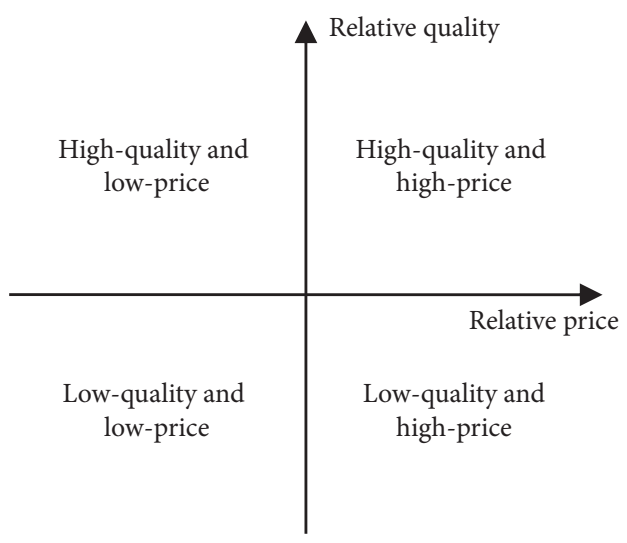

Figure 1: Enterprise's exporting competition strategy.

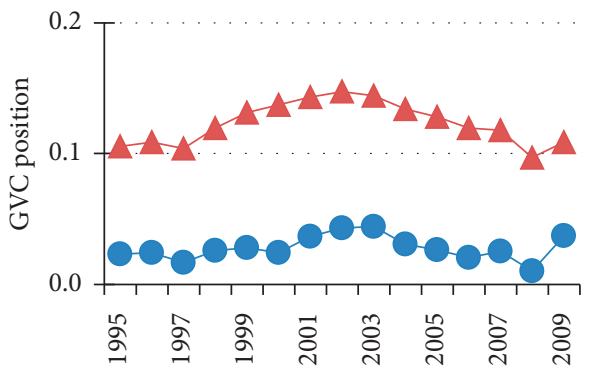

(a)

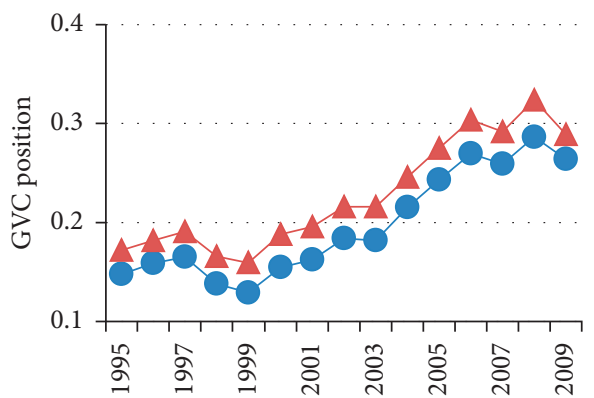

(d)

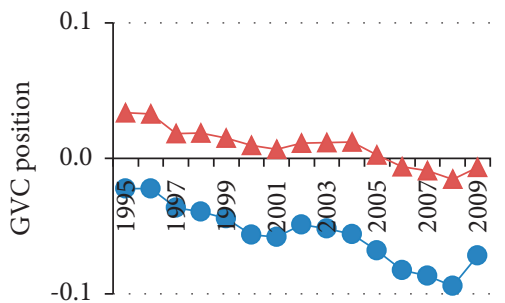

(b)

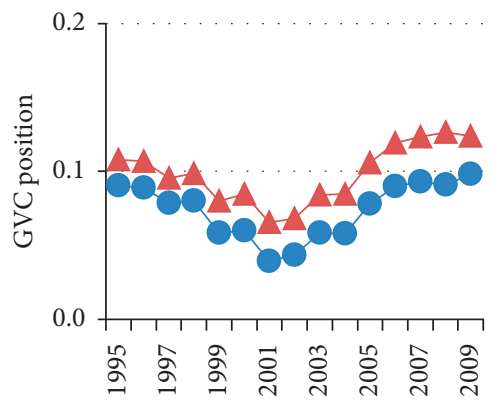

(e)

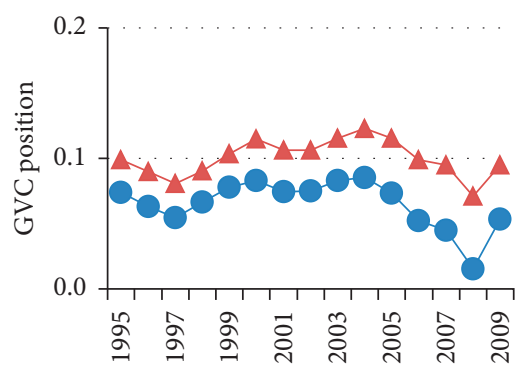

(c)

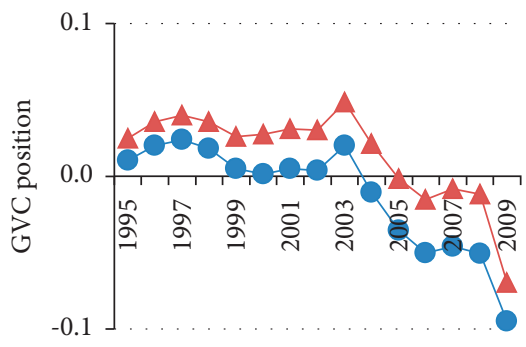

(f)

FIGURE 2: Major countries' GVC position over the period of 1995-2009. Note. The blue line is the GVC position before the improvement, and the red line is the GVC position after the improvement. (a) USA. (b) Germany. (c) Japan. (d) Russia. (e) Brazil. (f) India.

3.3. Statistical Analysis. We adopted the income method to measure enterprises' labor income share. Based on the data acquired, the work remuneration is measured by total payable wages and total payable welfare funds, and capital income refers to business surplus and depreciation. The formula of labor income share is described as follows:

Labor Income Share $=\frac{\text { total payable wages }+ \text { total payable welfare funds }}{\text { total payable wages }+ \text { total payable welfare funds }+ \text { business surplus }+ \text { depreciation }}$.

Table 1 depicts the competition strategy, target markets' GVC position, and labor income share of China's manufacturing exporting enterprises. The proportion of low-quality and low-price competitive strategies among the full sample of enterprises is $46 \%$, indicating that low-quality and low-price strategy is the most important competitive strategy of Chinese manufacturing export enterprises. Seeing from the exporting destination, for the high-quality and high-price strategy adopters, developed countries are their preference compared with nondeveloped ones, while the opposite applies to the low-quality and low-price adopters. Enterprises exporting to developed countries 
TABLE 1: Description of China's manufacturing exporting enterprises.

\begin{tabular}{|c|c|c|c|c|c|c|c|}
\hline & \multicolumn{4}{|c|}{ Competition strategy } & \multirow[b]{2}{*}{$\begin{array}{l}\text { GVC position of } \\
\text { target markets }\end{array}$} & \multirow{2}{*}{$\begin{array}{l}\text { Labor } \\
\text { income } \\
\text { share }\end{array}$} & \multirow[b]{2}{*}{$\begin{array}{l}\text { The number } \\
\text { of samples }\end{array}$} \\
\hline & $\begin{array}{l}\text { High-quality } \\
\text { and high-price }\end{array}$ & $\begin{array}{l}\text { Low-quality } \\
\text { and low-price }\end{array}$ & $\begin{array}{l}\text { High-quality } \\
\text { and low-price }\end{array}$ & $\begin{array}{l}\text { Low-quality } \\
\text { and high-price }\end{array}$ & & & \\
\hline $\begin{array}{l}\text { Complete sample } \\
\text { Exporting } \\
\text { destination }\end{array}$ & 0.21 & 0.46 & 0.21 & 0.12 & 0.030 & 0.45 & 185400 \\
\hline Developed countries & 0.23 & 0.44 & 0.22 & 0.11 & 0.048 & 0.47 & 124814 \\
\hline $\begin{array}{l}\text { Nondeveloped } \\
\text { countries } \\
\text { Competitors }\end{array}$ & 0.17 & 0.51 & 0.21 & 0.11 & -0.008 & 0.42 & 60586 \\
\hline Developed countries & 0.24 & 0.42 & 0.25 & 0.09 & 0.019 & 0.41 & 91722 \\
\hline $\begin{array}{l}\text { Developing } \\
\text { countries }\end{array}$ & 0.18 & 0.47 & 0.20 & 0.15 & 0.036 & 0.45 & 19607 \\
\hline $\begin{array}{l}\text { Domestic enterprises } \\
\text { Exporting products } \\
\text { type }\end{array}$ & 0.18 & 0.51 & 0.17 & 0.14 & 0.041 & 0.50 & 74071 \\
\hline Intermediates & 0.21 & 0.46 & 0.25 & 0.08 & 0.020 & 0.40 & 91108 \\
\hline Capital goods & 0.19 & 0.48 & 0.17 & 0.16 & 0.044 & 0.52 & 75339 \\
\hline $\begin{array}{l}\text { Consumer goods } \\
\text { Whether imports }\end{array}$ & 0.33 & 0.32 & 0.26 & 0.09 & 0.019 & 0.44 & 18864 \\
\hline Imports & 0.29 & 0.36 & 0.25 & 0.10 & 0.034 & 0.42 & 75499 \\
\hline $\begin{array}{l}\text { Nonimports } \\
\text { Ownership }\end{array}$ & 0.16 & 0.53 & 0.19 & 0.12 & 0.027 & 0.48 & 109901 \\
\hline $\begin{array}{l}\text { Foreign-funded } \\
\text { enterprises }\end{array}$ & 0.26 & 0.39 & 0.23 & 0.12 & 0.037 & 0.46 & 72121 \\
\hline $\begin{array}{l}\text { Nonforeign-funded } \\
\text { enterprises } \\
\text { Productivity }\end{array}$ & 0.18 & 0.50 & 0.20 & 0.12 & 0.025 & 0.45 & 113279 \\
\hline High productivity & 0.30 & 0.24 & 0.43 & 0.03 & 0.027 & 0.35 & 61800 \\
\hline $\begin{array}{l}\text { Medium } \\
\text { productivity }\end{array}$ & 0.22 & 0.50 & 0.17 & 0.11 & 0.030 & 0.47 & 61800 \\
\hline Low productivity & 0.11 & 0.63 & 0.05 & 0.21 & 0.032 & 0.54 & 61800 \\
\hline
\end{tabular}

Data resource: calculated based on the above method and data, the data of competition strategy and labor income share represents the respective share, and their classification is stated in the following part.

have higher target markets GVC position and enjoy higher labor income share. Such phenomenon can be naturally attributed to the fact that developed countries are more sensitive to quality while developing countries are more sensitive to price, and developed counties have higher GVC positions than developing ones. Competitor investigation shows that China's manufacturing exporting enterprises are more inclined to adopt a high-quality and high-price strategy facing competitors from developed countries compared with facing other competitors. And low-quality and low-price strategy appears more often in the competition among domestic enterprises. With regard to exporting products type, enterprises exporting consumer goods tend to choose high-quality and high-price strategy compared with those exporting intermediates and capital goods. Business scope also affects the enterprise's strategy. For enterprises that only export but not import, low-quality and low-price strategy is their preference, and they have a higher labor income share than those that both export and import. By firm ownership and productivity status, foreignowned firms and high-productivity firms have a larger share of exporting using a high-quality, high-price competitive strategy than nonforeign-owned, low-productivity firms.

\section{Theoretic Mechanism and Model Construction}

4.1. Analysis of Theoretic Mechanism. Suppose that there are two factors of production labor $(L)$ and capital $(K)$, and the factor prices are the wage rate $(w)$ and the interest rate $(r)$, respectively. Without considering government tax subsidies, the labor income share (ls) is ls $=w L /(w L+r K)$, which is deformed to give

$$
\text { ls }=\frac{1}{1+[(K / L) /(w / r)]} .
$$

From the above equation, it is clear that the labor income share depends on the factor use ratio $(K / L)$ and the relative factor price $(w / r)$.

The effect of the competitive strategy of the firm's participation in the target market GVC on the labor income share depends on the change in the factor use ratio and the relative factor price of the exported product. Specifically, there are two paths of action as follows: first, the factor intensity effect. Assuming that there is quality heterogeneity in the products exported by firms in country A to country $\mathrm{B}$ of the target market, the factor use ratio $(K / L)$ required for high-quality products is usually greater than 
that for low-quality products, and the adoption of quality competition strategy increases the capital-labor ratio of firms and thus reduces the labor income share. Assume that there are differences in consumer preferences in target market B. Target markets with high GVC status pay more attention to product quality, while target markets with low GVC status are more sensitive to the product price. Export product quality affects the factor use ratio of firms, while export product prices affect the relative factor prices through the price transmission mechanism. For target markets with different GVC statuses, there are differences in the extent to which firms focus on the quality and price of export products. Therefore, the impact of firms' competitive strategy choice on labor income share is related to the target market GVC status. Second, factor substitution effect, competitive strategy choice, and adjustment change the proportion of factors used by firms in country $\mathrm{A}$, and the relative prices of factors change accordingly. According to Bai and Qian [62], the rise in relative factor prices $(w / r)$ prompts firms to use capital instead of labor, which in turn leads to an increase in the factor use ratio $(K / L)$. At this point, judging the direction of change in the labor income share requires comparing which grows faster, the factor use ratio or the relative price. When the factor substitution elasticity is greater than one, the factor use ratio grows faster than the relative price of factors and the labor income share decreases; when the factor substitution elasticity is less than one, the labor income share increases.

According to Antoniades' endogenous decision model of a firm's export quality [63], the quality of a firm's export products in country A is related to the degree of competition in the target market. As shown in Figure 3, firms choose the optimal export product quality and marginal cost (inversely proportional to productivity), and firms with higher productivity have higher export product quality. When the degree of competition in the target market increases, the quality ladder shifts to the left, and the product quality varies more between firms. Firms with higher productivity respond to market competition by increasing product quality and price (region D1), firms with lower productivity respond by decreasing product quality and price (region D2), and firms with the lowest productivity exit the market (region D3). Firms adopt different competitive strategies (quality competition and price competition) depending on the target market GVC status, which has an impact on the labor income share. When the degree of competition in the target market changes, the higher the target market GVC status, the more likely the firm will adjust to a quality competition strategy; the lower the target market GVC status, the more likely the firm will adjust to a price competition strategy.

4.2. Econometric Model and Variables. Based on the above theoretic analysis, we built the following basic regression model to inspect the effect of the competition strategy an enterprise adopts for GVC participation on its labor income share.

$$
l s_{i t}=\beta_{0}+\beta_{1} c s_{i t}+\beta_{2} g v c_{i t}+\beta_{3} x_{i t}+\varepsilon_{i t} .
$$

In this model, $l s_{i t}$ denotes labor income share, $c s_{i t}$ is the competition strategy, $g v c_{i t}$ represents the GVC position of enterprises' exporting target market, and $x_{i t}$ refers to a series of control variables including financing constraints $f c_{i t}$, export intensity $e s_{i t}$, the size of enterprise $\operatorname{size}_{i t}$, and the age of enterprises age $e_{i t} \cdot \varepsilon_{i t}$ is the error term with subscript $i$ and $t$ being enterprise and the year, respectively.

Being the explained variable, exporting enterprises' labor income share $\left(l s_{i t}\right)$ can be measured as the above. Since labor income share is valued between 0 and 1 (the labor income share of enterprises in loss may be larger than 1 or less than 0 ; we did not take these enterprises into consideration), such limitation will bring bias to the statistical results. To avoid bias, we borrowed the method of Li et al. and Wei et al. to conduct Logist transformation to transform labor income share $l s_{i t}$ into $l s_{i t} /\left(1-l s_{i t}\right)$ and took the natural logarithm of it $[1,64]$.

The core explanatory variables include enterprises' competition strategy $\left(c s_{i t}\right)$ and the target market's GVC position $\left(g v c_{i t}\right)$. Competition strategy can be divided into high-quality and high-price strategy $c s 0_{i t}$, low-quality and low-price strategy $c s 1_{i t}$, high-quality and high-price strategy $c s 2_{\text {it }}$, and low-quality and high-price strategy $c s 3_{i t}$ based on the relative quality $r q_{i t}$ and relative price $r p_{i t}$ of enterprises' exporting goods. The target market's GVC position is measured in the method said before.

We set four control variables. Among them, financing constraints $\left(f c_{i t}\right)$ facing enterprises are measured by debtto-assets ratio, details of which can be searched in Luo and Chen [65], export intensity $\left(e s_{i t}\right)$ is measured by enterprises' export volume-to-sales ratio, enterprise size $\left(\right.$ size $\left._{i t}\right)$ is depicted by its total assets, and enterprise's age $\left(\mathrm{age}_{i t}\right)$ is calculated by subtracting its establishing year from the current year and then adding 1 .

For the division of export destinations of enterprises, according to the number of enterprise exports, the proportion of exports to developed countries exceeds $50 \%$ is defined as mainly exporting to developed countries, otherwise mainly exporting to nondeveloped countries (according to the classification rule of United Nations Developed Program, Australia, Austria, Belgium, Canada, Czech Republic, Denmark, Finland, Germany, France, Greece, Hungary, Iceland, Ireland, Italy, Japan, South Korea, Luxemburg, Netherland, New Zealand, Norway, Poland, Portugal, Slovakia, Spain, Sweden, Switzerland, the United States, Great Britain, Andorra, Bahrain, Barbados, Brunei, Cyprus, Estonia, Hong Kong, Israel, Liechtenstein, Malta, Monaco, Qatar, Slovenia, Singapore, and United Arab Emirates belong to developed countries and regions, others belonging to developing countries and regions). Applying the BACI database, the respective share of certain products exporting to one country from developed countries and developing countries except China and China can be obtained. Based on the China Customs database, we can calculate the share of the product exporting to the country from different enterprises. Matching products with its exporting destination, we can get the share of the product exporting to the country from enterprises of developed countries, developing countries except China, and other Chinese 


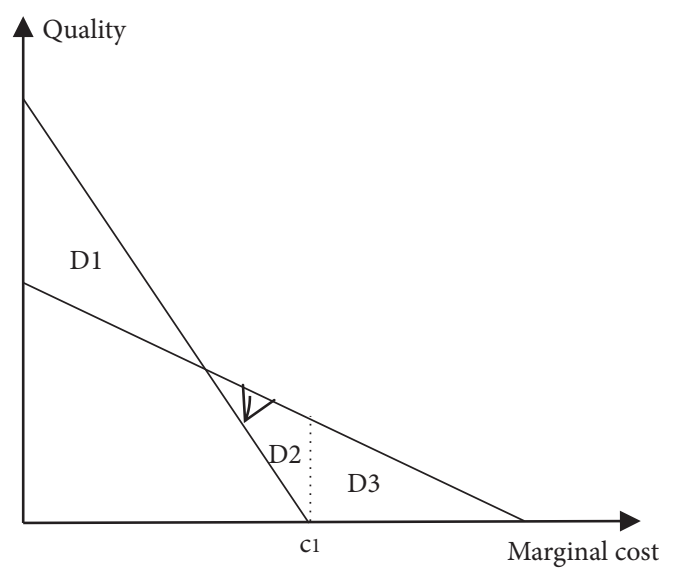

Figure 3: Competitive strategy and degree of competition in the target market (source: [63]).

enterprises. According to BEC, we classified enterprises' exporting products into intermediates, capital goods, and consumer goods, dropping the few other categories. The enterprise location is divided into the eastern region, central region, and western region. Provinces and cities including Beijing, Tianjin, Hebei province, Liaoning province, Shanghai, Jiangsu province, Zhejiang province, Fujian province, Shandong province, and Guangdong province belong to the eastern region. The central region covers Shanxi province, Jilin province, Heilongjiang province, Anhui province, Jiangxi province, Henan province, Hubei province, and Hunan province, other provinces being the western region.

Data in this paper are collected from China Industrial Enterprise Database over the period of 2000-2007, China Customs Statistic Database, BACI database, WIOD Database over 1995-2011, and data supplied by Brandt et al. and Feenstra and Romalis $[24,54]$. The industry concordance of HS code in each year, SITC industrial classification, and $\mathrm{BEC}$ product category were borrowed from the United Nations Database, and the RMB exchange rate against the US dollar is searched from the Chinese Statistical Yearbook. We constructed a harmonized classification that groups China's Industrial Enterprises Database and China Customs Statistical Database. In length, we used the name of enterprises to match these two databases and then matched the postal code of the enterprise's location with the last sevendigit number of the enterprise's telephone number. Next, we matched the simplified enterprise's name without address and ownership with the postal code. Finally, we retain enterprises successfully matched with at least one of the above methods as our samples. These data were processed using Feenstra et al. methodology [66]. We excluded observations showing missing, zero, or negative values of total assets, net fixed assets, total wage bills, industrial sales, and the number of employees and further dropped all firms with less than 8 employees. We treat observations with more net fixed assets than total assets or without enterprise code similarly and those with no or less than zero of paid-in capital. We also dropped the largest and smallest 1 percent of observations.

\section{Empirical Analysis}

The panel dataset of China's exporting enterprises conducting general trade over 2000-2007 is applied to inspect the effect of enterprises' GVC participation competition strategy on its labor income share. The whole process is conducted as follows. First, a two-way fixed effects model is used for estimation and the basic results are analyzed to draw basic conclusions. Second, in order to exclude possible sample selection bias, endogeneity problems, etc., indicator substitution, subsampling, and different estimation methods are used for robustness tests, respectively; finally, interaction terms are added to the regressions to further test the effects of interactions between different variables on labor income shares.

5.1. Benchmark Estimates. We first conduct OLS regression for all samples. Results show the maximum variance inflation factor is 1.77 , far below the threshold value of 10 , excluding severe multicollinearity among variables. To see the influence of exporting enterprises' competition strategy on its labor income share, we used the relative exporting price and relative quality as explaining variables to make regression. Seeing from column (1) and column (2) in Table 2 , the elasticity coefficient of relative exporting price is 0.021 , which is significant at the 1 percent level, showing the positive effect of exporting price on labor income share. With other conditions being the same, higher exporting price incurring larger labor share may be due to the fact that labor factor price is more sensitive to exporting product price than capital factor price did. Statistical results show that about half of Chinese enterprises adopt low-quality and low-price strategy, and the export is more reliable on labor than on other factors, to some extent that explains why labor income share is greatly affected. The elasticity coefficient of relative exporting quality is -0.023 significant at the 1 percent level, presenting that relative exporting quality significantly lowered labor income share. This may be attributed to the positive relationship between export quality and capital intensity which was found in Fan and Guo [36]. With other conditions being the same, enterprises with higher exporting quality tend to have a lower labor share. Comparing the estimate coefficients, we can see that the quality competition showed larger effect on labor income share than price competition did. To make deeper exploitation, we check the effect of four bundles of competition strategies on labor income share one by one and in conjunction in the following part of this paper. (By setting the variable of certain competition strategy as 1 and others as 0 , we check the effect of this strategy. To avoid complete collinearity, we set highquality and high-price strategy as contract term when taking all competition strategies into the regression model.)

Column (3) and column (5) in Table 2 show the significant negative effect of high-quality and high-price strategy as well as high-quality and low-price strategy on labor income share, while results in columns (4) and (6) tell the significant positive effect of low-quality and low-price strategy and low-quality and high-price strategy on the labor share. Both verified the major role quality strategy played in labor income share, which is 
TABLE 2: Benchmark estimate results.

\begin{tabular}{|c|c|c|c|c|c|c|c|}
\hline & $(1)$ & $(2)$ & (3) & $(4)$ & (5) & $(6)$ & $(7)$ \\
\hline$R p$ & $\begin{array}{l}0.021^{* * *} \\
(0.0026)\end{array}$ & $\begin{array}{l}0.021^{* * *} \\
(0.0026)\end{array}$ & & & & & \\
\hline$R q$ & $\begin{array}{c}-0.230^{* * *} \\
(0.0048)\end{array}$ & $\begin{array}{c}-0.217^{* * *} \\
(0.0048)\end{array}$ & & & & & \\
\hline $\operatorname{cs} 0$ & & & $\begin{array}{c}-0.096^{* * *} \\
(0.0078)\end{array}$ & & & & \\
\hline $\operatorname{cs} 1$ & & & & $\begin{array}{l}0.138^{* * *} \\
(0.0066)\end{array}$ & & & $\begin{array}{l}0.214^{* * *} \\
(0.0093)\end{array}$ \\
\hline $\operatorname{cs} 2$ & & & & & $\begin{array}{c}-0.153^{* * *} \\
(0.0070)\end{array}$ & & $\begin{array}{c}-0.026^{* * *} \\
(0.0087)\end{array}$ \\
\hline $\operatorname{cs} 3$ & & & & & & $\begin{array}{l}0.114^{* * *} \\
(0.0085)\end{array}$ & $\begin{array}{l}0.241^{* * *} \\
(0.0106)\end{array}$ \\
\hline$g v c$ & & $\begin{array}{c}-0.166^{* * *} \\
(0.0570)\end{array}$ & $\begin{array}{c}-0.197^{* * *} \\
(0.0574)\end{array}$ & $\begin{array}{c}-0.190^{* * *} \\
(0.0574)\end{array}$ & $\begin{array}{c}-0.192^{* * *} \\
(0.0574)\end{array}$ & $\begin{array}{c}-0.197^{* * *} \\
(0.0574)\end{array}$ & $\begin{array}{c}-0.162^{* * *} \\
(0.0572)\end{array}$ \\
\hline$f_{c}$ & & $\begin{array}{l}0.617^{* * *} \\
(0.0176)\end{array}$ & $\begin{array}{l}0.634^{* * *} \\
(0.0178)\end{array}$ & $\begin{array}{c}0.632^{* * *} \\
(0.0177)\end{array}$ & $\begin{array}{l}0.633^{* * *} \\
(0.0177)\end{array}$ & $\begin{array}{c}0.634^{* * *} \\
(0.0178)\end{array}$ & $\begin{array}{l}0.629^{* * *} \\
(0.0177)\end{array}$ \\
\hline es & & $\begin{array}{l}0.111^{* * *} \\
(0.0138)\end{array}$ & $\begin{array}{l}0.143^{* * *} \\
(0.0139)\end{array}$ & $\begin{array}{l}0.136^{* * *} \\
(0.0139)\end{array}$ & $\begin{array}{l}0.139^{* * *} \\
(0.0139)\end{array}$ & $\begin{array}{l}0.145^{* * *} \\
(0.0139)\end{array}$ & $\begin{array}{l}0.126^{* * *} \\
(0.0139)\end{array}$ \\
\hline Size & & $\begin{array}{c}-0.207^{* * *} \\
(0.0064)\end{array}$ & $\begin{array}{c}-0.245^{* * *} \\
(0.0064)\end{array}$ & $\begin{array}{c}-0.245^{* * * *} \\
(0.0064)\end{array}$ & $\begin{array}{c}-0.244^{* * *} \\
(0.0064)\end{array}$ & $\begin{array}{c}-0.244^{* * *} \\
(0.0064)\end{array}$ & $\begin{array}{c}-0.239^{* * *} \\
(0.0064)\end{array}$ \\
\hline Age & & $\begin{array}{l}0.015^{* * *} \\
(0.0007)\end{array}$ & $\begin{array}{l}0.012^{* * *} \\
(0.0007)\end{array}$ & $\begin{array}{l}0.012^{* * *} \\
(0.0007)\end{array}$ & $\begin{array}{l}0.012^{* * *} \\
(0.0007)\end{array}$ & $\begin{array}{l}0.012^{* * *} \\
(0.0007)\end{array}$ & $\begin{array}{l}0.012^{* * *} \\
(0.0007)\end{array}$ \\
\hline Observations & 185400 & 185400 & 185400 & 185400 & 185400 & 185400 & 185400 \\
\hline Year FE & Yes & Yes & Yes & Yes & Yes & Yes & Yes \\
\hline Firm FE & Yes & Yes & Yes & Yes & Yes & Yes & Yes \\
\hline$R^{2}$ & 0.020 & 0.045 & 0.029 & 0.031 & 0.032 & 0.029 & 0.038 \\
\hline
\end{tabular}

${ }^{* * *},{ }^{* *}$, and ${ }^{*}$ respectively, indicate significance at $1 \%, 5 \%$, and $10 \%$. The values in the bracket indicate the standard error, the same below.

consistent with the estimates of respective checks for price competition and quality competition. China's exporting enterprises mainly adopt the low-quality and low-price strategy, leading to a relatively large labor income share. However, with the increase in export quality, labor income share goes down. From column (7), compared with the high-quality and highprice strategy, low-quality and low-price strategy and lowquality and high-price strategy incurred higher labor share, while the high-quality and low-price strategy tends to lower the labor income share of exporting enterprises. Concluded from this, with export quality being the same, lower exporting price results in lower labor income share, while with the same exporting price, lower quality leads to higher labor share. Considering the both, quality competition plays the major role.

The estimated coefficient of the target market's GVC position is negative, indicating that exporting to markets with higher GVC position tend to lower the enterprises' labor income share, consistent with our expectation. Countries with high GVC positions are more possible to conduct capital-intensive production while relocating laborintensive procedures to other countries such as China. However, such procedures are more likely to be labor-intensive for Chinese producers. What's more, the choice of target market may be related to enterprises' competition strategy, which will be further illustrated in the following sections.

For the estimation of other control variables, the estimated coefficients of financing constraints are significantly positive, indicating that exporting firms with greater financing constraints have higher labor income shares. Facing tighter financing, enterprises choose labor as a substitution of capital, thus increasing the labor income share. Our estimates are different from the analysis conducted for all Chinese enterprises by Luo and Chen [65] since exporting enterprises can play the labor advantage by participating in GVC production. The coefficient of enterprises' exporting intensity is also significantly positive, showing that being more inclined to export, the enterprise enjoys a larger labor income share, which is similar to the conclusion of Zhou et al. [16]. Enterprise's size presents a negative effect on labor income share. Enterprises with larger sizes have a smaller share of labor income. Finally, the elder enterprises tend to have a larger labor income share since the estimate of the enterprise's age is positive.

5.2. Robustness Check. We have modified some index measurements in the benchmark estimate, which may bring bias to the results. Therefore, this paper employs different alternative indicators and uses different estimation methods for robustness testing. In detail, we take government tax subsidies into consideration when measuring labor income share. The methodology of Koopman et al. is applied to measure the target market's GVC position [60]. We use the median value instead of the average as a reference when defining competition strategy. As for the methods, we adopt Tobit estimation in replace of Logist transformation method and take balanced panel samples excluding the effect of the entry into and exit from the export market on enterprise's labor income share instead of unbalanced ones. Table 3 
TABLE 3: The estimate of regressions using substitute variables and methods.

\begin{tabular}{lccccc}
\hline & & Substitute variables & & \multicolumn{2}{c}{ Substitute methods } \\
& Labor income share & GVC position & Competition strategy & Tobit & Balanced panel \\
\hline$c s 1$ & $0.241^{* * *}(0.0084)$ & $0.222^{* * *}(0.0093)$ & $0.209^{* * *}(0.0088)$ & $0.207^{* * *}(0.0076)$ & $0.226^{* * *}(0.0289)$ \\
$c s 2$ & $-0.026^{* * *}(0.0078)$ & $-0.025^{* * *}(0.0087)$ & $-0.030^{* * *}(0.0083)$ & $-0.207^{* * *}(0.0090)$ & $0.018(0.0254)$ \\
$c s 3$ & $0.272^{* * *}(0.0096)$ & $0.255^{* * *}(0.0106)$ & $0.242^{* * *}(0.0089)$ & $0.381^{* * *}(0.0104)$ & $0.242^{* * *}(0.0352)$ \\
$g v c$ & $-0.133^{* * *}(0.0517)$ & $-0.163^{* * *}(0.0627)$ & $-0.160^{* * *}(0.0572)$ & $-0.135^{* * *}(0.0383)$ & $-0.261(0.2058)$ \\
$f c$ & $0.504^{* * *}(0.0160)$ & $0.568^{* * *}(0.0177)$ & $0.630^{* * *}(0.0177)$ & $0.993^{* * *}(0.0118)$ & $0.675^{* * *}(0.0641)$ \\
$e s$ & $0.288^{* * *}(0.0125)$ & $0.135^{* * *}(0.0140)$ & $0.126^{* * *}(0.0139)$ & $0.283^{* * *}(0.0101)$ & $-0.081^{*}(0.0432)$ \\
Size & $-0.162^{* * *}(0.0058)$ & $-0.218^{* * *}(0.0071)$ & $-0.238^{* * *}(0.0064)$ & $-0.203^{* * *}(0.0024)$ & $-0.131^{* * *}(0.0202)$ \\
Age & $0.012^{* * *}(0.0007)$ & $0.006^{* * *}(0.0007)$ & $0.012^{* * *}(0.0007)$ & $0.014^{* * *}(0.0004)$ & $0.012^{* * *}(0.0019)$ \\
Observations & 185400 & 185400 & 185,400 & 185400 & 8632 \\
Year FE & Yes & Yes & Yes & Yes & Yes \\
Firm FE & Yes & Yes & Yes & - & Yes \\
$R^{2}$ & 0.041 & 0.025 & 0.038 & & 0.059 \\
\hline
\end{tabular}

shows the same estimate results after taking substitute variables and almost the same results using the Tobit method and balanced panel samples. We can say that the estimate of the effect of enterprises' GVC participation strategy on labor income share is somewhat robust. (The estimated results of balanced panel samples did not show a significant negative effect of the target market's GVC position on labor income share. This may be due to the fact that enterprises have made effective integration of production procedures taking place in different target markets.)

5.3. The Effect of Enterprises' Heterogeneity. The above estimates show the effect from enterprises of the average level. Disparities in factors including target market choice, competitors, exporting product types, ownership, and differences in factor endowments in enterprises' locations may also affect the influence of enterprises' GVC participation strategy on its labor income share. To take these factors into consideration, we need to make a classification of samples to exploit the effect of the enterprise's heterogeneity on the benchmark results.

5.3.1. Heterogeneity in Target Market and Competitors. The estimation results are presented in Table 4, which divides the subsample into six categories of firms according to their target markets and competitors, the main target markets for GVC participation into developed countries and developing countries, and the main competitors into developed, developing, and domestic Chinese firms. All the samples are classified into six subsamples. Results show that the coefficient of low-quality and low-price strategy is positive for all target markets and competitors, indicating the low-quality and low-price strategy adopted by Chinese enterprises in whatever target markets and facing any competitors tend to have a positive effect on their labor income share. This is true in reality. Chinese enterprises usually take advantage of their low labor costs. Using a lot of low-skilled labor will increase the labor income share. There exist significant differences in the effect of the high-quality and low-price strategy on labor income share when enterprises choose different target markets and face variant competitors. When competing with developing countries in developed countries or competing with developed countries in developing countries, the high-quality and low-price strategy tends to have a significant negative effect on exporting enterprises' labor income share, while in other cases, the estimated coefficient is not significant. This may be due to the fact that developed countries are more focused on product quality. When competing with enterprises from developed countries in their hometown, Chinese enterprises will not choose the quality strategy. While facing competitors from developing countries, to some extent we have a quality advantage, and the high-quality and low-price strategy is beneficial for Chinese enterprises' GVC participation. Based on this, choosing a high-quality and low-price strategy when competing with developing countries' competitors in developed countries will lower Chinese enterprises' labor income share. Developing countries are more sensitive to product prices than developed countries. Chinese enterprises have no price advantage competing with competitors from developing countries and from home, so they are not choosing the high-quality and low-price strategy. But in competition with developed countries, the high-quality and low-price strategy is a better choice. In light of this, choosing a high-quality and low-price strategy when competing with developed countries in developing countries significantly lowers Chinese enterprises' labor income share. The low-quality and high-price strategy showed a positive effect on labor income share except when competing with developing competitors in developed countries. The estimation results for the other control variables are broadly consistent with the basic estimation results.

5.3.2. Heterogeneity in Export Product Structures and in Total Factor Productivity. Since export product structure and total factor productivity do affect the labor income share to some extent [67], we have classified samples based on these two influencing factors. From the results shown in Table 5, we can see that the estimate for the low-quality and low-price strategy as well as low-quality and high-price strategy is the same for all subsamples, showing a positive effect on labor income share. However, the high-quality and low-price strategy is playing different roles in subsamples with different product 
TABLE 4: The estimate of subsamples classified by target market and competitors.

\begin{tabular}{|c|c|c|c|c|c|c|}
\hline \multirow{2}{*}{$\begin{array}{l}\text { Target } \\
\text { market } \\
\text { Competitors }\end{array}$} & \multicolumn{3}{|c|}{ Developed countries } & \multicolumn{3}{|c|}{ Developing countries } \\
\hline & $\begin{array}{c}\text { Enterprises from } \\
\text { developed countries }\end{array}$ & $\begin{array}{c}\text { Enterprises from } \\
\text { developing countries }\end{array}$ & $\begin{array}{c}\text { Chinese } \\
\text { enterprises }\end{array}$ & $\begin{array}{c}\text { Enterprises from } \\
\text { developed countries }\end{array}$ & $\begin{array}{c}\text { Enterprises from } \\
\text { developed countries }\end{array}$ & $\begin{array}{l}\text { Chinese } \\
\text { enterprises }\end{array}$ \\
\hline $\operatorname{cs} 1$ & $0.238^{* * *}(0.0169)$ & $0.191^{* * *}(0.0506)$ & $\begin{array}{l}0.240^{* * *} \\
(0.0207)\end{array}$ & $0.170^{* * *}(0.0240)$ & $0.158^{*}(0.0827)$ & $\begin{array}{l}0.201^{* * *} \\
(0.0430)\end{array}$ \\
\hline $\operatorname{cs} 2$ & $-0.010(0.0146)$ & $-0.133^{* * *}(0.0497)$ & $\begin{array}{c}-0.006 \\
(0.0210)\end{array}$ & $-0.046^{* *}(0.0204)$ & $-0.040(0.0823)$ & $\begin{array}{c}-0.014 \\
(0.0464)\end{array}$ \\
\hline $\operatorname{cs} 3$ & $0.239^{* * *}(0.0208)$ & $0.181^{* * *}(0.0522)$ & $\begin{array}{l}0.272^{* * *} \\
(0.0218)\end{array}$ & $0.251^{* * *}(0.0298)$ & $0.130(0.0942)$ & $\begin{array}{l}0.211^{* * *} \\
(0.0450)\end{array}$ \\
\hline$f_{c}$ & $0.710^{* * *}(0.0342)$ & $0.722^{* * *}(0.0991)$ & $\begin{array}{l}0.551^{* * *} \\
(0.0356)\end{array}$ & $0.705^{* * *}(0.0503)$ & $0.193(0.1244)$ & $\begin{array}{l}0.531^{* * *} \\
(0.0658)\end{array}$ \\
\hline es & $0.062^{* *}(0.0269)$ & $0.021(0.0698)$ & $\begin{array}{l}0.216^{* * *} \\
(0.0274)\end{array}$ & $0.120^{* * *}(0.0427)$ & $-0.007(0.1496)$ & $\begin{array}{l}0.116^{* *} \\
(0.0492)\end{array}$ \\
\hline Size & $-0.229^{* * *}(0.0120)$ & $-0.216^{* * *}(0.0384)$ & $\begin{array}{c}-0.256^{* * *} \\
(0.0144)\end{array}$ & $-0.261^{* * *}(0.0168)$ & $-0.119^{* *}(0.0582)$ & $\begin{array}{c}-0.274^{* * *} \\
(0.0238)\end{array}$ \\
\hline Age & $0.014^{* * *}(0.0014)$ & $0.023^{* * *}(0.0044)$ & $\begin{array}{l}0.018^{* * *} \\
(0.0018)\end{array}$ & $0.008^{* * *}(0.0018)$ & $-0.005(0.0052)$ & $\begin{array}{l}0.005^{* *} \\
(0.0026)\end{array}$ \\
\hline Observations & 58562 & 12372 & 53880 & 33160 & 7235 & 20191 \\
\hline Year FE & Yes & Yes & Yes & Yes & Yes & Yes \\
\hline Firm FE & Yes & Yes & Yes & Yes & Yes & Yes \\
\hline$R^{2}$ & 0.041 & 0.043 & 0.040 & 0.041 & 0.020 & 0.039 \\
\hline
\end{tabular}

TABLE 5: The estimated results of regressions on subsamples classified by product category and total factor productivity.

\begin{tabular}{|c|c|c|c|c|c|c|}
\hline & \multicolumn{3}{|c|}{ Export product category } & \multicolumn{3}{|c|}{ Total factor productivity } \\
\hline & Intermediates & Consumer goods & Capital goods & Low & Medium & High \\
\hline$c s 1$ & $0.214^{* * *}(0.0131)$ & $0.234^{* * *}(0.0162)$ & $0.185^{* * *}(0.0293)$ & $0.160^{* * *}(0.0237)$ & $0.105^{* * *}(0.0175)$ & $0.090^{* * *}(0.0183)$ \\
\hline $\operatorname{cs} 2$ & $-0.031^{* *}(0.0120)$ & $-0.020(0.0167)$ & $-0.000(0.0222)$ & $0.021(0.0305)$ & $-0.015(0.0168)$ & $-0.028^{* *}(0.0128)$ \\
\hline $\operatorname{cs} 3$ & $0.248^{* * *}(0.0161)$ & $0.249^{* * *}(0.0170)$ & $0.232^{* * *}(0.0344)$ & $0.171^{* * *}(0.0233)$ & $0.141^{* * *}(0.0204)$ & $0.083^{* * *}(0.0322)$ \\
\hline$g v c$ & $-0.082(0.0797)$ & $-0.327^{* * *}(0.1018)$ & $-0.136(0.1911)$ & $-0.240^{* *}(0.1212)$ & $-0.235^{* *}(0.1114)$ & $-0.196^{*}(0.1053)$ \\
\hline$f_{c}$ & $0.679^{* * *}(0.0263)$ & $0.552^{* * *}(0.0275)$ & $0.707^{* * *}(0.0593)$ & $0.556^{* * *}(0.0388)$ & $0.506^{* * *}(0.0354)$ & $0.704^{* * *}(0.0327)$ \\
\hline es & $0.077^{* * *}(0.0214)$ & $0.170^{* * *}(0.0208)$ & $0.075(0.0483)$ & $0.063^{* *}(0.0272)$ & $0.065^{* *}(0.0265)$ & $0.118^{* * *}(0.0294)$ \\
\hline Size & $-0.234^{* * *}(0.0092)$ & $-0.243^{* * *}(0.0108)$ & $-0.206^{* * *}(0.0195)$ & $-0.209^{* * *}(0.0157)$ & $-0.108^{* * *}(0.0135)$ & $-0.195^{* * *}(0.0115)$ \\
\hline Age & $0.011^{* * *}(0.0010)$ & $0.014^{* * *}(0.0014)$ & $0.011^{* * *}(0.0020)$ & $0.014^{* * *}(0.0016)$ & $0.015^{* * *}(0.0013)$ & $0.016^{* * *}(0.0014)$ \\
\hline Observations & 91108 & 75339 & 18864 & 61800 & 61800 & 61800 \\
\hline Year FE & Yes & Yes & Yes & Yes & Yes & Yes \\
\hline Firm FE & Yes & Yes & Yes & Yes & Yes & Yes \\
\hline$R^{2}$ & 0.040 & 0.042 & 0.033 & 0.020 & 0.028 & 0.035 \\
\hline
\end{tabular}

categories and different productivities. By export product category, the high-quality and low-price strategy has a significant negative effect on the labor income share of enterprises mainly exporting intermediates, the same as benchmark results. But the negative effect of such strategy is not significant for enterprises' major conduct consumer goods and capital goods export, similar to the process of trade liberalization improving the quality of imported intermediates [68]. Trade liberalization has intensified the competition of intermediates export market, and enterprises tend to choose a high-quality and low-price strategy rather than a high-quality and high-price strategy to participate in international competition. Facing international competition of consumer goods, enterprises usually have some market powers and prefer the high-quality and high-price strategy. With developing countries as its target market of capital goods export, China is more likely to adopt te low-quality and low-price strategy. (Results in Table 1 showed that most enterprises exporting consumer goods adopt the high-quality and high-price strategy, while those exporting capital goods prefer the low-quality and low-price strategy.) The target market's GVC position has a significant positive effect on labor income share for enterprises that mainly export consumer goods and has an insignificant positive effect for those that mainly export capital goods and intermediates. This may be attributed to the trade pattern that consumer goods exporting to developed countries are of higher quality, and developing countries are the target markets for capital goods export. Seeing from productivity, the high-quality and lowprice strategy has a significant negative effect on labor income share of enterprises with high productivity while it has an insignificant effect for enterprises with medium and low productivity. Productivity is positively correlated with product quality [36], and low and medium productivity firms have lower product quality and may not be in a position to adopt a high-quality and low-price strategy. 
TABLE 6: The estimated results of regressions on subsamples classified by ownership and regions.

\begin{tabular}{|c|c|c|c|c|c|c|}
\hline & \multicolumn{3}{|c|}{ Ownership } & \multicolumn{3}{|c|}{ Regions } \\
\hline & $\begin{array}{l}\text { State-owned/collective- } \\
\text { owned enterprises }\end{array}$ & $\begin{array}{c}\text { Private } \\
\text { enterprises }\end{array}$ & $\begin{array}{l}\text { Foreign-funded/Hong Kong, } \\
\text { Macau, and Taiwan enterprises }\end{array}$ & $\begin{array}{l}\text { Eastern } \\
\text { region }\end{array}$ & $\begin{array}{l}\text { Central } \\
\text { region }\end{array}$ & $\begin{array}{l}\text { Western } \\
\text { region }\end{array}$ \\
\hline $\operatorname{cs} 1$ & $0.149^{* * *}(0.0392)$ & $\begin{array}{c}0.176^{* * *} \\
(0.0129)\end{array}$ & $0.256^{* * *}(0.0150)$ & $\begin{array}{l}0.215^{* * *} \\
(0.0096)\end{array}$ & $\begin{array}{l}0.211^{* * *} \\
(0.0444)\end{array}$ & $\begin{array}{c}0.209^{* * *} \\
(0.0526)\end{array}$ \\
\hline $\operatorname{cs} 2$ & $-0.031(0.0364)$ & $\begin{array}{r}-0.028^{* *} \\
(0.0124)\end{array}$ & $-0.014(0.0136)$ & $\begin{array}{c}-0.026^{* * *} \\
(0.0090)\end{array}$ & $0.034(0.0413)$ & $\begin{array}{r}-0.106^{* *} \\
(0.0471)\end{array}$ \\
\hline $\operatorname{cs} 3$ & $0.153^{* * *}(0.0454)$ & $\begin{array}{l}0.191^{* * *} \\
(0.0145)\end{array}$ & $0.296^{* * *}(0.0173)$ & $\begin{array}{c}0.241^{* * *} \\
(0.0109)\end{array}$ & $\begin{array}{c}0.324^{* * *} \\
(0.0518)\end{array}$ & $\begin{array}{c}0.147^{* *} \\
(0.0627)\end{array}$ \\
\hline$g v c$ & $-0.136(0.2330)$ & $\begin{array}{c}-0.074 \\
(0.0782)\end{array}$ & $-0.227^{* *}(0.0946)$ & $\begin{array}{c}-0.166^{* * *} \\
(0.0597)\end{array}$ & $\begin{array}{c}-0.352 \\
(0.2532)\end{array}$ & $0.341(0.3076)$ \\
\hline$f_{c}$ & $0.249^{* * *}(0.0791)$ & $\begin{array}{l}0.608^{* * *} \\
(0.0242)\end{array}$ & $0.742^{* * *}(0.0296)$ & $\begin{array}{l}0.630^{* * * *} \\
(0.0185)\end{array}$ & $\begin{array}{l}0.676^{* * *} \\
(0.0771)\end{array}$ & $\begin{array}{l}0.522^{* * *} \\
(0.0967)\end{array}$ \\
\hline es & $0.077(0.0665)$ & $\begin{array}{l}0.144^{* * *} \\
(0.0183)\end{array}$ & $0.092^{* * *}(0.0236)$ & $\begin{array}{l}0.130^{* * *} \\
(0.0144)\end{array}$ & $0.059(0.0661)$ & $0.071(0.0870)$ \\
\hline Size & $-0.249^{* * *}(0.0345)$ & $\begin{array}{c}-0.245^{* * *} \\
(0.0082)\end{array}$ & $-0.298^{* * *}(0.0123)$ & $\begin{array}{c}-0.230^{* * *} \\
(0.0067)\end{array}$ & $\begin{array}{c}-0.305^{* * *} \\
(0.0289)\end{array}$ & $\begin{array}{c}-0.406^{* * *} \\
(0.0385)\end{array}$ \\
\hline Age & $-0.002(0.0018)$ & $\begin{array}{l}0.004^{* * *} \\
(0.0009)\end{array}$ & $0.055^{* * *}(0.0019)$ & $\begin{array}{l}0.014^{* * *} \\
(0.0008)\end{array}$ & $\begin{array}{c}-0.003 \\
(0.0024)\end{array}$ & $\begin{array}{l}0.007^{* *} \\
(0.0029)\end{array}$ \\
\hline Observations & 13828 & 99451 & 72121 & 166211 & 12390 & 6799 \\
\hline Year FE & Yes & Yes & Yes & Yes & Yes & Yes \\
\hline Firm FE & Yes & Yes & Yes & Yes & Yes & Yes \\
\hline$R^{2}$ & 0.019 & 0.046 & 0.048 & 0.039 & 0.040 & 0.049 \\
\hline
\end{tabular}

5.3.3. Heterogeneity of Ownership, Region, and Industry. For enterprises of different ownership and in different regions, the low-quality and low-price strategy and low-quality and high-price strategy have shown the same positive effect on their labor income share, as shown in Table 6. The highquality and low-price strategy plays a significant negative effect on private enterprises and those in eastern regions while it has an insignificant effect on other subsamples, which has been verified in Li et al. [32]. They have found that private enterprises and eastern region enterprises are more likely to adopt the high-quality and low-price strategy in international competition and pass on the losses from highquality and low-price competitive strategies to labor. The estimated coefficients of GVC status in the target market show that the higher the GVC status of foreign firms and eastern region firms exporting to countries with higher GVC status, the lower their labor income share, and foreign firms or eastern region firms exporting mainly to developed countries have relatively higher capital-labor ratios of their export products.

Table 7 shows the estimates of regressions on subsamples classified by industries. Results are almost the same as the benchmark regressions for most industries. However, for industries of beverage manufacturing, wood processing industry, printing industry, petroleum processing, and chemical fiber manufacturing industry, the effects of competition strategy on labor income share are not significant.

5.3.4. Endogeneity Problem. Considering the possible omission of explanatory variables affecting labor income share in this paper, and the possible mutual causality between firms' competitive strategies for participating in GVC and labor income share, this can lead to the endogeneity problem.
In this paper, a two-way fixed effects model is used in the empirical test to control the endogeneity problem to some extent. Since no effective instrumental variables are found, this paper uses the difference method to examine the dynamic relationship between variables. The difference method can eliminate a part of the endogeneity problem caused by omitted variables that do not change over time and alleviate the endogeneity problem to some extent, thus weakening the influence of endogeneity on the conclusions of this paper. Firstly, relative quality and relative price are regressed after making the difference, and the results are shown in (1) and (2) of Table 8. Then, the differential of competitive strategy is defined according to the differential of relative price and relative quality of firms' exports, and if both relative price and relative quality of exports increase compared with the previous period, it is defined as the differential of high quality and high price; i.e., the differential of high quality and high price indicates that both relative quality and relative price increase compared with the previous period, and the differential of other competitive strategies is redefined similarly. The estimation results of the difference method for competitive strategies are shown in (3)-(7) of Table 8. The signs and significance of the estimated coefficients of relative price and relative quality of firms' exports are consistent with the basic estimation results, and the effects of the competitive strategies constructed using relative price and relative quality on labor income shares are similar to the basic estimation results. The estimated coefficients of the target market GVC position are not significant, indicating that exporters choose to participate in the target market GVC mainly by choosing the horizontal position of GVC position rather than the increment of GVC position. The effect of firms' export intensity on labor income share is also not significantly related to its increment, and the estimated results of other variables are consistent with the basic estimation results. 
TABLE 7: The estimated results of regressions on subsamples classified by industries.

\begin{tabular}{|c|c|c|c|c|}
\hline Industry code and name & $\begin{array}{c}\text { Low-quality and } \\
\text { low-price }\end{array}$ & $\begin{array}{c}\text { High-quality and } \\
\text { low-price }\end{array}$ & $\begin{array}{c}\text { Low-quality and } \\
\text { high-price }\end{array}$ & Observations \\
\hline 13 Farm and sideline food processing industry & $0.270^{* * *}$ & $-0.245^{* * *}$ & $0.154^{* * *}$ & 8539 \\
\hline 14 Food industry & $0.164^{* * *}$ & $-0.196^{* * *}$ & $0.189^{* *}$ & 3741 \\
\hline 15 Beverage manufacturing & 0.126 & -0.109 & -0.065 & 1151 \\
\hline 17 Textile industry & $0.103^{* * *}$ & $-0.170^{* * *}$ & $0.112^{* * *}$ & 20622 \\
\hline 18 Textile clothing, shoes, and hat manufacturing & $0.085^{* * *}$ & $-0.207^{* * *}$ & $0.071^{* * *}$ & 16356 \\
\hline 19 Leather, fur, and feather manufacturing & $0.095^{* * *}$ & $-0.142^{* * *}$ & $0.048^{*}$ & 8194 \\
\hline $\begin{array}{l}20 \text { Wood processing and wood, bamboo, rattan, palm grass } \\
\text { products industry }\end{array}$ & 0.029 & $-0.091^{*}$ & 0.071 & 3617 \\
\hline 21 Furniture manufacturing & $0.205^{* * *}$ & $-0.255^{* * *}$ & $0.134^{* * *}$ & 3745 \\
\hline 22 Paper making and paper products industry & $0.117^{*}$ & $-0.145^{* *}$ & $0.481^{* * *}$ & 1861 \\
\hline 23 Printing and recording media replication & -0.033 & 0.015 & 0.077 & 1257 \\
\hline 24 Cultural education and sports goods & $0.113^{* * *}$ & $-0.131^{* * *}$ & $0.123^{* * *}$ & 6019 \\
\hline $\begin{array}{l}25 \text { Petroleum processing, coking and nuclear fuel } \\
\text { processing }\end{array}$ & 0.038 & -0.065 & 0.234 & 728 \\
\hline $\begin{array}{l}26 \text { Chemical raw materials and chemical products } \\
\text { manufacturing }\end{array}$ & $0.210^{* * *}$ & $-0.205^{* * *}$ & $0.162^{* * *}$ & 10952 \\
\hline 27 Pharmaceutical industry & $0.179^{* * *}$ & $-0.073^{* *}$ & $0.141^{* *}$ & 3043 \\
\hline 28 Chemical fiber manufacturing & 0.093 & 0.015 & 0.090 & 670 \\
\hline 29 Rubber products & $0.109^{* *}$ & -0.069 & $0.109^{*}$ & 2565 \\
\hline 30 Plastic products & $0.123^{* * *}$ & $-0.153^{* * *}$ & $0.154^{* * *}$ & 7891 \\
\hline 31 Nonmetal mineral products & $0.174^{* * *}$ & $-0.141^{* * *}$ & $0.135^{* *}$ & 9103 \\
\hline 32 Black metal smelting and rolling processing industry & $0.137^{* *}$ & $-0.173^{* *}$ & $0.165^{*}$ & 1710 \\
\hline $\begin{array}{l}33 \text { Nonferrous metal smelting and rolling processing } \\
\text { industry }\end{array}$ & $0.090^{*}$ & $-0.257^{* * *}$ & $0.207^{* *}$ & 1983 \\
\hline 34 Metal products & $0.125^{* * *}$ & $-0.164^{* * *}$ & $0.132^{* * *}$ & 10923 \\
\hline 35 Ordinary machinery manufacturing & $0.180^{* * *}$ & $-0.128^{* * *}$ & $0.105^{* * *}$ & 14329 \\
\hline 36 Special equipment manufacturing & $0.142^{* * *}$ & $-0.100^{* * *}$ & $0.134^{* * *}$ & 7082 \\
\hline 37 Transportation equipment manufacturing & $0.169^{* * *}$ & $-0.200^{* * *}$ & $0.155^{* * *}$ & 8119 \\
\hline 39 Electrical machinery and equipment manufacturing & $0.125^{* * *}$ & $-0.134^{* * *}$ & $0.113^{* * *}$ & 12289 \\
\hline $\begin{array}{l}40 \text { Communication equipment, computer, and other } \\
\text { electronic equipment manufacturing }\end{array}$ & $0.097^{* * *}$ & $-0.080^{* * *}$ & $0.145^{* * *}$ & 8956 \\
\hline 41 Instrument and culture, office machinery manufacturing & $0.094^{* *}$ & $-0.089^{* *}$ & $0.166^{* *}$ & 3704 \\
\hline 42 Handicrafts and other manufacturing & $0.147^{* * *}$ & $-0.177^{* * *}$ & $0.177^{* * *}$ & 6238 \\
\hline
\end{tabular}

TABLE 8: Estimation results of the difference method.

\begin{tabular}{|c|c|c|c|c|c|c|c|}
\hline & $(1)$ & $(2)$ & (3) & $(4)$ & (5) & (6) & (7) \\
\hline$\Delta r p$ & $\begin{array}{l}0.013^{* * *} \\
(0.0035)\end{array}$ & $\begin{array}{l}0.014^{* * *} \\
(0.0034)\end{array}$ & & & & & \\
\hline$\Delta r q$ & $\begin{array}{c}-0.177^{* * *} \\
(0.0070)\end{array}$ & $\begin{array}{c}-0.180^{* * *} \\
(0.0069)\end{array}$ & & & & & \\
\hline$\Delta c s 0$ & & & $\begin{array}{c}-0.116^{* * *} \\
(0.0086)\end{array}$ & & & & \\
\hline$\Delta c s 1$ & & & & $\begin{array}{l}0.145^{* * *} \\
(0.0093)\end{array}$ & & & $\begin{array}{c}0.182^{* * *} \\
(0.0106)\end{array}$ \\
\hline$\Delta c s 2$ & & & & & $\begin{array}{c}-0.133^{* * *} \\
(0.0094)\end{array}$ & & $\begin{array}{l}-0.021^{*} \\
(0.0109)\end{array}$ \\
\hline$\Delta c s 3$ & & & & & & $\begin{array}{l}0.159^{* * *} \\
(0.0107)\end{array}$ & $\begin{array}{l}0.203^{* * *} \\
(0.0121)\end{array}$ \\
\hline$\Delta g v c$ & & $0.079(0.0835)$ & $0.060(0.0838)$ & $0.068(0.0838)$ & $0.072(0.0838)$ & $0.065(0.0838)$ & $0.080(0.0835)$ \\
\hline$\Delta f c$ & & $\begin{array}{c}0.589^{* * *} \\
(0.0260)\end{array}$ & $\begin{array}{c}0.587^{* * *} \\
(0.0261)\end{array}$ & $\begin{array}{c}0.589^{* * *} \\
(0.0261)\end{array}$ & $\begin{array}{c}0.589^{* * *} \\
(0.0261)\end{array}$ & $\begin{array}{l}0.586^{* * *} \\
(0.0261)\end{array}$ & $\begin{array}{l}0.584^{* * *} \\
(0.0260)\end{array}$ \\
\hline$\Delta e s$ & & $0.015(0.0195)$ & $0.028(0.0196)$ & $0.027(0.0196)$ & $0.031(0.0196)$ & $0.030(0.0196)$ & $0.019(0.0195)$ \\
\hline$\Delta$ Size & & $\begin{array}{c}-0.286^{* * *} \\
(0.0131)\end{array}$ & $\begin{array}{c}-0.284^{* * *} \\
(0.0131)\end{array}$ & $\begin{array}{c}-0.284^{* * *} \\
(0.0131)\end{array}$ & $\begin{array}{c}-0.284^{* * *} \\
(0.0131)\end{array}$ & $\begin{array}{c}-0.284^{* * *} \\
(0.0131)\end{array}$ & $\begin{array}{c}-0.287^{* * *} \\
(0.0131)\end{array}$ \\
\hline Observations & 97265 & 97265 & 97265 & 97265 & 97265 & 97265 & 97265 \\
\hline Year FE & Yes & Yes & Yes & Yes & Yes & Yes & Yes \\
\hline Firm FE & Yes & Yes & Yes & Yes & Yes & Yes & Yes \\
\hline$R^{2}$ & 0.011 & 0.028 & 0.020 & 0.021 & 0.020 & 0.021 & 0.027 \\
\hline
\end{tabular}


TABLE 9: The estimate results of regressions introducing interact terms.

\begin{tabular}{|c|c|c|c|c|c|c|}
\hline & $(1)$ & $(2)$ & (3) & $(4)$ & (5) & (6) \\
\hline$c s 0$ & $-0.106^{* * *}(0.0083)$ & & & & $-0.098^{* * *}(0.0078)$ & \\
\hline$c s 0 \times g v c$ & $-0.285^{* * *}(0.0923)$ & & & & & \\
\hline$c s 1$ & & $0.140^{* * *}(0.0071)$ & & & & $0.110^{* * *}(0.0089)$ \\
\hline$c s 1 \times g v c$ & & $0.056(0.0677)$ & & & & \\
\hline $\operatorname{cs} 2$ & & & $-0.157^{* * *}(0.0076)$ & & & \\
\hline$c s 2 \times g v c$ & & & $-0.097(0.0855)$ & & & \\
\hline $\operatorname{cs} 3$ & & & & $0.111^{* * *}(0.0094)$ & & \\
\hline$c s 3 \times g v c$ & & & & $-0.088(0.1075)$ & & \\
\hline$c s 0 \times i c r$ & & & & & $0.298^{*}(0.1597)$ & \\
\hline $\operatorname{cs} 1 \times$ ent & & & & & & $0.065^{* * *}(0.0099)$ \\
\hline$g v c$ & & & & & $-0.196^{* * *}(0.0574)$ & $-0.251^{* * *}(0.0796)$ \\
\hline$f_{c}$ & $0.633^{* * *}(0.0178)$ & $0.632^{* * *}(0.0177)$ & $0.633^{* * *}(0.0177)$ & $0.634^{* * *}(0.0178)$ & $0.634^{* * *}(0.0178)$ & $0.672^{* * *}(0.0237)$ \\
\hline es & $0.142^{* * *}(0.0139)$ & $0.135^{* * *}(0.0139)$ & $0.139^{* * *}(0.0139)$ & $0.145^{* * *}(0.0139)$ & $0.143^{* * *}(0.0139)$ & $0.150^{* * *}(0.0192)$ \\
\hline Size & $-0.245^{* * *}(0.0064)$ & $-0.245^{* * *}(0.0064)$ & $-0.244^{* * *}(0.0064)$ & $-0.244^{* * *}(0.0064)$ & $-0.245^{* * *}(0.0064)$ & $-0.251^{* * *}(0.0091)$ \\
\hline Age & $0.012^{* * *}(0.0007)$ & $0.012^{* * *}(0.0007)$ & $0.012^{* * *}(0.0007)$ & $0.012^{* * *}(0.0007)$ & $0.012^{* * *}(0.0007)$ & $0.007^{* * *}(0.0010)$ \\
\hline Observations & 185400 & 185400 & 185400 & 185400 & 185400 & 103251 \\
\hline Year FE & Yes & Yes & Yes & Yes & Yes & Yes \\
\hline Firm FE & Yes & Yes & Yes & Yes & Yes & Yes \\
\hline$R^{2}$ & 0.029 & 0.031 & 0.032 & 0.029 & 0.029 & 0.034 \\
\hline
\end{tabular}

5.3.5. Further Discussions. In order to test the possible association between exporters' participation in GVC in choosing their target market and their competitive strategy, as well as the effect of the interaction between other variables on labor income share, this paper adds an interaction term to further test. Results are depicted in Table 9. Column 1 has presented the results introducing interactions between the target market's GVC position and high-quality and highprice strategy. The estimate coefficients are all negative, showing the interactions have significantly affected the influence on labor income share. With the increase in the target market's GVC position, the negative effect of the highquality and high-price strategy on labor income share is enlarged. This may be due to the fact that countries with higher GVC positions paid more attention to product quality and enterprises exporting to these countries preferred the high-quality and high-price strategy, increasing the capital intensity of products while forcing down the labor income share [36]. This is consistent with the conclusions of Flach that enterprises exporting to high-income countries tend to adopt the high-quality and high-price strategy [69]. Columns 2 to 4 showed the estimated results after introducing interactions between low-quality and low-price strategy, high-quality and low-price strategy, and lowquality and high-price strategy and target market's GVC position; results did not show a significant effect on labor income share. Fan et al. found that enterprises exporting high-quality products to countries with higher GVC positions are more likely to import high-quality intermediates [70]. Due to this, we introduced interactions between import intermediates contained in enterprises' export and highquality and high-price strategy, and estimated coefficients in column 5 are significantly positive, showing that importing intermediates in export production eased the negative effect of the high-quality and high-price strategy on labor income share. This can be explained by the fact that the high quality of exporting goods can be attributed to importing high- quality intermediates and thus lowered the capital intensity of the production procedure. However, we did not find interactions existing between import intermediates in enterprises' export with other competitive strategies. Li concluded that newly entered enterprises are more likely to adopt a price competition strategy [32]. Based on this, we check the effect of interactions between the entry of enterprises and the low-quality and low-price strategy. (We borrowed the three-year judgment rule proposed by Li et al. to define the entry and exit of enterprises [33].) Significant positive estimates in column 6 told us that enterprises' new entry into export markets has enlarged the positive effect of the low-quality and low-price strategy on labor income share.

\section{Conclusions}

Based on the existing literature, this paper portrays the competitive strategies of firms' participation in GVC and examines the impact of firms' competitive strategies of participation in GVC on labor income share from the perspective of target market selection using data of Chinese manufacturing firms from 2000 to 2007. Conclusions are as follows.

First, with export product quality being the same, with higher exporting prices, enterprises enjoy higher labor income share. With the same exporting price, exporting products of higher quality will lower the enterprise's labor income share. Compared with price competition, quality competition showed a larger effect on labor income share.

Second, both high-quality and high-price competition strategies have significant negative effects on labor income share, while both low-quality and low-price competition strategies have significant positive effects on labor income share. The positive effect of the low-quality and low-price strategy and low-quality and high-price strategy does not vary among heterogeneous enterprises, while labor income 
share will receive various effects from the high-quality and low-price strategy due to enterprises' heterogeneity. Only when competing with developing countries in developed markets or competing with developed countries in developing markets, the high-quality and high-price strategy will play a significant positive role in affecting labor income share. The high-quality and low-price strategy has laid a positive-negative effect on eastern private enterprises' labor income share.

Third, the higher the GVC status of the target market when firms participate in GVC, the lower the labor income share of exporting firms. But introducing import intermediates will ease the negative effect of the high-quality and high-price strategy. The new market entry by firms amplifies the positive effect of the low-quality, low-price strategy on labor income share.

The $19^{\text {th }}$ National Congress of the Communist Party of China has proposed that we must adhere to the first place of quality and efficiency and keep in line with supply-side reform and push forward the revolution of quality, efficiency, and driving force in economic development to improve total factor productivity. Although in a short period, the low-quality and low-price strategy did ease the decrease in China's labor income share to some extent in GVC production, with the aging of the population, the export competitiveness by virtue of cheap labor will not last. Based on improving products quality and enterprises' benefit, we aim to apply quality competition instead of traditional price competition to shoot more trade benefits in GVC and to assure a certain share of laborers' wage income in the primary distribution of national income. In addition, Chinese exporters should take "One Belt, One Road" as an opportunity to reshape their competitive strategy of participating in global value chains and build a regional value chain division of labor system led by themselves.

\section{Data Availability}

The data presented in this study are available on request from the corresponding author.

\section{Conflicts of Interest}

The authors declare no conflicts of interest.

\section{Acknowledgments}

This research was funded by Project of Philosophy and Social Science Foundation of Guangdong (No. GD20YYJ05), Foundation of Natural Science of Guangdong (No. 2019BT02H594), major Project of National Social Science Foundation of China (No. 21ZDA097), and Project of Humanities and Social Science Research Youth Foundation of Ministry of Education (No. 18YJC630050).

\section{References}

[1] D. Li, L. Liu, and H. Wang, "The U curve of labor share in GDP during economic development," Economic Research Journal, no. 1, pp. 70-82, 2009.
[2] X. Lu and L. Tian, "Firms' size differentiation and labor income share," The Journal of World Economy, no. 9, pp. 27-48, 2020.

[3] Y. Su, C. Chen, and J. Lan, "VAT Reform and labor income share: evidence from Chinese listed companies," Finance and Trade Economics, no. 3, pp. 44-61, 2021.

[4] J. Wan and X. Wei, "The impact of minimum wage regulation on the labor income share of enterprises: theoretical analysis and micro-evidence," Journal of Finance and Economics, no. 7, pp. 64-78, 2020.

[5] X. Shi, W. Gao, Y. Lu, and M. Li, "Capital market allocation efficiency and labor income share: evidence from the sharetrading reform," Economic Research Journal, no. 12, pp. 21-37, 2019.

[6] D. Chen and S. Chen, "The relative price of capital labor, the elasticity of substitution and labor income share," The Journal of World Economy, no. 12, pp. 73-97, 2018.

[7] W. F. Stolper and P. A. Samuelson, "Protection and real wages," The Review of Economic Studies, vol. 9, no. 1, pp. 58-73, 1941.

[8] A. E. Harrison, Has Globalization Eroded Labor's Share? Some Cross-Country Evidence, University Library of Munich, Munich, Germany, Article ID 39649, 2005.

[9] D. Acemoglu, "Changes in unemployment and wage inequality: an alternative theory and some evidence," The American Economic Review, vol. 89, no. 5, pp. 1259-1278, 1999.

[10] L. Karabarbounis and B. Neiman, "The global decline of the labor share," Quarterly Journal of Economics, vol. 129, no. 1, pp. 61-103, 2014.

[11] B. Decreuse and P. Maarek, "Can the HOS model explain changes in labor shares? A tale of trade and wage rigidities," Economic Systems, vol. 41, no. 4, pp. 472-491, 2017.

[12] M. W. L. Elsby, B. Hobijn, and A. Şahin, "The decline of the U.S. labor share," Brookings Papers on Economic Activity, no. 2, pp. 1-63, 2013.

[13] P. Bai and Z. Yang, "The bargaining power of labor and the proportion of labor income: an analysis of the impact of the financial crisis," Management World, no. 5, pp. 78-91, 2019.

[14] S. Xie, Y. Lu, and X. Cai, "The wage bargaining power of workers in an open economic system," Social Sciences in China, no. 5, pp. 40-59, 2019.

[15] D. Tang, "Globalization and labor income share: an analysis based on the bargaining strength between labor and capital," Management World, no. 8, pp. 23-33, 2011.

[16] Z. Zhou, H. Quan, and T. Chen, "Export, effect of deep labor division and labor income share," Journal of International Trade, no. 2, pp. 16-26, 2017.

[17] X. Wu and J. Shao, "Research on the heterogeneity impact of export participation on labor income share of manufacturing enterprises," Journal of International Trade, no. 1, pp. 14-27, 2019.

[18] J. Zhang, Z. Chen, and X. Zhou, "Research on the inhibitory effects of exporting on labor's share," The Journal of Quantitative \& Technical Economics, no. 7, pp. 44-60, 2012.

[19] L. Zhang, J. Li, and X. Xu, "International trade, biased technological progress and factor income distribution," China Economic Quarterly, vol. 11, pp. 410-428, 2012.

[20] W. Xiao and M. Zhou, "Change of trade mode and decrease of labor share: empirical evidence from China's industrial sector," Journal of ZheJiang University (Humanities and Social Sciences), vol. 40, no. 5, pp. 154-163, 2010.

[21] Z. Peng and B. Zhang, “The evolution of China's international division of labor income and the decomposition of its 
determinants," China Industrial Economics, no. 6, pp. 62-80, 2018.

[22] X. Huang, S. Xu, and J. Lu, "Trade liberalisation and labour income share variation: an interpretation of China's deviation from the ss," The World Economy, vol. 34, no. 7, pp. 1071-1087, 2011.

[23] P. Böckerman and M. Maliranta, "Globalization, creative destruction, and labor share change: evidence on the determinants and mechanisms from longitudinal plant-level data," Oxford Economic Papers, vol. 64, pp. 259-280, 2012.

[24] L. Brandt, J. Van Biesebroeck, and Y. Zhang, "Creative accounting or creative destruction? Firm-Level productivity growth in Chinese manufacturing," Journal of Development Economics, vol. 97, no. 2, pp. 339-351, 2012.

[25] M. Yu and Z. Liang, “Trade liberalization and China's labor income share: empirical analysis based on data of manufacturing trading enterprises," Management World, no. 6, pp. 54-63, 2014.

[26] R. N. Ahsan and D. Mitra, "Trade liberalization and labor's slice of the pie: evidence from Indian firms," Journal of Development Economics, vol. 108, pp. 1-16, 2014.

[27] Z. Liu and J. Zhang, "Forming breakthrough and strategies of captive network in developing countries at global outsourcing system: based on a comparative survey of GVC and NVC," China Industrial Economics, no. 5, pp. 39-47, 2007.

[28] G. Gereffi and J. Lee, "Why the world suddenly cares about global supply chains," Journal of Supply Chain Management, vol. 48, no. 3, pp. 24-32, 2012.

[29] G. Sui, Z. Sun, and W. Chen, "Global value chain embeddedness and labor income share: based on China's theory and empirical analysis," Journal of International Trade, no. 2, pp. 96-112, 2021.

[30] G. Sui, Z. Sun, and W. Chen, "Upstream degree of global value chain, FDI and factor income distribution of manufacturing enterprises," International Economics and Trade Research, no. 11 , pp. 52-66, 2020.

[31] P. Jin, "Holding to the solid foundation of real economic development," Qiushi, no. 7, pp. 24-26, 2012.

[32] K. Li, W. Jiang, and L. Song, "The mystery of changes in the quality of China's exports: a micro-level explanation based on market entry," Social Sciences in China, no. 3, pp. 80-103, 2014.

[33] Y. Liu and Y. Ding, "Has China realized quality-driven export growth in ICT industry: an empirical study based on three margins and gravity equation," China Industrial Economics, no. 1, pp. 52-64, 2015.

[34] H. Han and C. Yu, "Price competition or quality competition: an empirical study on the competitiveness of China's export products," Industrial Economic Review, no. 6, pp. 127-135, 2014.

[35] X. Li, J. Zhou, X. Lu, and J. Hu, "Does the export product quality affect export volume," Economic Research Journal, no. 8, pp. 114-129, 2015.

[36] H. Fan and G. Guo, "The relationship between exporting price, exporting quality and productivity: evidence from China," The Journal of World Economy, no. 2, pp. 58-85, 2015.

[37] E. Dinopoulos, S. Kalyvitis, and M. Katsimi, "Variable export price elasticity, product quality, and credit constraints: theory and evidence from Greek firms," Journal of International Economics, vol. 104, Article ID 102135, 2020.

[38] X. Dai and P. Jin, "Intra-product specialization, institution quality and export sophistication," Economic Research Journal, no. 7, pp. 4-17, 2014.
[39] C. Luo and N. Wei, "The price effect of Chian's export: evidence from products of machinery and transport equipment," Finance \& Trade Economics, no. 8, pp. 104-118, 2015.

[40] F. Li, "Export competition and export quality of Chinese enterprises," Journal of Dalian University of Technolgy, vol. 36, no. 3, pp. 86-92, 2015.

[41] D. Sheng and Y. Wang, "The mystery of the low-price exports of China's enterprises: an analysis from the perspective of enterprise's markup ratio," Management World, no. 5, pp. 8-23, 2012.

[42] H. Fan, Y. Li, S. Xu, and S. R. Yeaple, "Quality, variable markups, and welfare: a quantitative general equilibrium analysis of export prices," Journal of International Economics, vol. 125, Article ID 103327, 2020.

[43] T. Zhong and M. Yu, "External demand, competitive strategy and export behavior of multi-product enterprises," China Industrial Economics, no. 10, pp. 119-137, 2020.

[44] A. Maurer and C. Degain, "Globalization and trade flows: what you see is not what you get," Journal of International Commerce, Economics and Policy (JICEP), vol. 3, pp. 1-27, 2012.

[45] X. Gao, J. Huang, and K. Yuan, "Value chain embedded position and export domestic value added rate," The Journal of Quantitative \&Technical Economics, no. 6, pp. 41-61, 2019.

[46] Z. Zhou and K. Zhu, "The factor ownership structure of foreign-funded enterprises and the attribution of export value-added income," China Industrial Economics, no. 1, pp. 118-135, 2020.

[47] S. Zhang, "Does global value chain lead to decrease of labor income share: empirical analysis of China's industrial panel data," Economic Perspectives, no. 10, pp. 39-48, 2015.

[48] S. Liu, N. Gu, and X. Chen, "Global value incorporation, factor endowments structure and the proportion of labor income: empirical study based on international data," The Economist, no. 3, pp. 96-104, 2016.

[49] P. Bastos and J. Silva, "The quality of a firm's exports: where you export to matters," Journal of International Economics, no. 2, pp. 99-111, 2010.

[50] K. Manova and Z. Zhang, "Export prices across firms and destinations," Quarterly Journal of Economics, vol. 127, no. 1, pp. 379-436, 2012.

[51] A. K. Khandelwal, P. K. Schott, and S.-J. Wei, “Trade liberalization and embedded institutional reform: evidence from Chinese exporters," The American Economic Review, vol. 103, no. 6, pp. 2169-2195, 2013.

[52] B. Shi and W. Shao, "The measurement and decisive factors of Chinese enterprises' exporting product quality," Management World, no. 9, pp. 90-106, 2014.

[53] J. Xu, J. Tong, and Q. Mao, "RMB exchange rate, product quality and firms'export activity: an empirical analysis based on Chinese manufacturing enterprises," Journal of Financial Research, no. 3, pp. 1-17, 2015.

[54] R. C. Feenstra and J. Romalis, "International prices and endogenous quality," Quarterly Journal of Economics, vol. 129, no. 2, pp. 477-527, 2014.

[55] M. Yu and R. Zhang, "Estimating China's manufacturing export quality: pitfalls and remedy," China Economic Quarterly, vol. 16, pp. 463-484, 2017.

[56] K. Li and W. Jiang, How Chinese Manufacturers Compete in Global Markets: Price Competition VS Quality Competition, Working Paper, 2016.

[57] S. Zhou, Z. Lan, and H. Fu, "Division status of China's manufacturing industry in global value chains: a study based 
on koopman's GVC position indices," Journal of International Trade, no. 2, pp. 3-12, 2014.

[58] S. Ma, H. Zhang, and X. Wang, "Financing constraints and moving up in the global value chain: theory and evidence from Chinese processing trade enterprises," Social Sciences in China, no. 1, pp. 83-107, 2017.

[59] W. Chen, P. Zhao, and J. Fang, "Chains' position, trade revenue and competitiveness in global value chains: an analysis based on trade in value added accounting framework," International Business Research, no. 4, pp. 5-18, 2017.

[60] R. Koopman, W. Powers, Z. Wang, and S. Wei, Give Credit where Credit Is Due: Tracing Value Added in Global Production Chains, NBER Working Paper, Cambridge, MA, USA, Article ID 16426, 2010.

[61] Z. Wang, S. Wei, and K. Zhu, Quantifying International Production Sharing at the Bilateral and Sector Levels, NBER Working Paper, Cambridge, MA, USA, Article ID 19677, 2013.

[62] C. Bai and Z. Qian, "Factor income share in chain: the story behind the statistics," Economic Research Journal, no. 3, pp. 27-41, 2009.

[63] A. Antoniades, "Heterogeneous firms, quality, and trade," Journal of International Economics, vol. 95, no. 2, pp. 263-273, 2015.

[64] X. Wei, Z. Dong, and Y. Liu, "Political relationship, system environment and labor income share: a study based on the investigation data of China's private enterprises," Management World, no. 5, pp. 35-46, 2013.

[65] C. Luo and L. Chen, "Does financial constraints lead to decline in labor income shares: an empirical study based on China's enterprise data supplied by world bank," Journal of Financial Research, no. 3, pp. 29-42, 2012.

[66] R. C. Feenstra, Z. Li, and M. Yu, "Exports and credit constraints under incomplete information: theory and evidence from China," The Review of Economics and Statistics, vol. 96, no. 4, pp. 729-744, 2014.

[67] X. Zhang and Y. Lu, "Effect of merchandise trade structure changes on labor income share," The Journal of Quantitative \& Technical Economics, no. 1, pp. 59-76, 2014.

[68] M. Yu and L. Li, "Trade liberalization and quality upgrading of intermediate inputs: evidence from Chinese customs data," China Economic Quarterly, vol. 15, pp. 1011-1028, 2016.

[69] L. Flach, "Quality upgrading and price heterogeneity: evidence from Brazilian exporters," Journal of International Economics, vol. 102, pp. 282-290, 2016.

[70] H. Fan, Y. A. Li, and S. R. Yeaple, "Trade liberalization, quality, and export prices," The Review of Economics and Statistics, vol. 97, no. 5, pp. 1033-1051, 2015. 